\title{
Glucose management for exercise using continuous glucose monitoring (CGM) and intermittently scanned CGM (isCGM) systems in type 1 diabetes: position statement of the European Association for the Study of Diabetes (EASD) and of the International Society for Pediatric and Adolescent Diabetes (ISPAD) endorsed by JDRF and supported by the American Diabetes Association (ADA)
}

\author{
Othmar Moser $^{1,2}$ (D) Michael C. Riddell ${ }^{3}$ (D) $\cdot$ Max L. Eckstein $^{1}$ (D) Peter Adolfsson ${ }^{4,5}$ (D) Rémi Rabasa-Lhoret ${ }^{6,7,8,9}$ (D) \\ Louisa van den Boom ${ }^{10}$ (D) Pieter Gillard $^{11}$ (D) Kirsten Nørgaard $^{12}$ (D) Nick S. Oliver ${ }^{13}$ (D) Dessi P. Zaharieva ${ }^{14}$ (D)

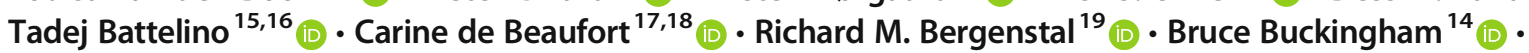 \\ Eda Cengiz $^{20,21}$ (D) - Asma Deeb ${ }^{22}$ (D) - Tim Heise ${ }^{23}$ (D) - Simon Heller ${ }^{24,25}$ (D) - Aaron J. Kowalski ${ }^{26}$ (D) \\ Lalantha Leelarathna $^{27,28}$ (D) - Chantal Mathieu ${ }^{11}$ (D) $\cdot$ Christoph Stettler $^{29}$ (D) Martin Tauschmann $^{30}$ (D) \\ Hood Thabit $^{27}$ (D) Emma G. Wilmot ${ }^{31,32}$ (D) Harald Sourij $^{1}$ (D) Carmel E. Smart $^{33,34}$ (D) Peter G. Jacobs ${ }^{35}$ (D) \\ Richard M. Bracken ${ }^{36}$ (D) Julia K. Mader $^{1}$ iD
}

Published online: 13 October 2020

(C) Jointly held by John Wiley \& Sons, and Springer-Verlag GmbH Germany, part of Springer Nature 2020

\begin{abstract}
Physical exercise is an important component in the management of type 1 diabetes across the lifespan. Yet, acute exercise increases the risk of dysglycaemia, and the direction of glycaemic excursions depends, to some extent, on the intensity and duration of the type of exercise. Understandably, fear of hypoglycaemia is one of the strongest barriers to incorporating exercise into daily life. Risk of hypoglycaemia during and after exercise can be lowered when insulin-dose adjustments are made and/or additional carbohydrates are consumed. Glycaemic management during exercise has been made easier with continuous glucose monitoring (CGM) and intermittently scanned continuous glucose monitoring (isCGM) systems; however, because of the complexity of CGM and isCGM systems, both individuals with type 1 diabetes and their healthcare professionals may struggle with the interpretation of given information to maximise the technological potential for effective use around exercise (i.e. before, during and after). This position statement highlights the recent advancements in CGM and isCGM technology, with a focus on the evidence base for their efficacy to sense glucose around exercise and adaptations in the use of these emerging tools, and updates the guidance for exercise in adults, children and adolescents with type 1 diabetes.
\end{abstract}

Keywords Adolescents · Adults · CGM · Children · Continuous glucose monitoring $\cdot$ Exercise $\cdot$ Physical activity $\cdot$ Position statement - Type 1 diabetes

This article is co-published in the journals Diabetologia and Pediatric Diabetes, available at https://doi.org/10.1007/s00125-020-05263-9 and https://onlinelibrary.wiley.com/journal/13995448, respectively.

This is an abridged version of the Position Statement. The full-length version is available on the EASD website.

Electronic supplementary material The online version of this article (https://doi.org/10.1007/s00125-020-05263-9) contains peer-reviewed but unedited supplementary material including a slideset of the figures for download, which is available to authorised users.

Othmar Moser

Othmar.moser@medunigraz.at

Extended author information available on the last page of the article 


\begin{tabular}{|c|c|}
\hline \multicolumn{2}{|c|}{ Abbreviations } \\
\hline ADL & Activities of daily living \\
\hline CGM & Continuous glucose monitoring \\
\hline IAH & Impaired awareness of hypoglycaemia \\
\hline isCGM & $\begin{array}{l}\text { Intermittently scanned continuous } \\
\text { glucose monitoring }\end{array}$ \\
\hline ISPAD & $\begin{array}{l}\text { International Society for Pediatric and } \\
\text { Adolescent Diabetes }\end{array}$ \\
\hline MARD & Mean absolute relative difference \\
\hline SMBG & Self-monitored blood glucose \\
\hline
\end{tabular}

\section{Introduction}

Most common continuous glucose monitoring (CGM) systems measure glucose in the interstitial fluid, providing real-time sensor glucose data, while intermittently scanned CGM (isCGM) systems measure interstitial glucose levels at the time of scanning via a reader device. CGM improves the time spent in euglycaemia and reduces (severe) hypoglycaemia in people with impaired awareness of hypoglycaemia (IAH), decreases $\mathrm{HbA}_{1 \mathrm{c}}$ levels and ameliorates general measures of glycaemic control, as shown in different randomised (crossover) studies [1-4]. isCGM reduces the time spent in hypoglycaemia, as shown by randomised controlled studies $[5,6]$, and decreases $\mathrm{HbA}_{1 \mathrm{c}}$ levels, as shown by a meta-analysis [7] of largely observational studies. Interestingly, switching from isCGM to CGM may have a beneficial impact on hypoglycaemia outcomes in people with a high risk of hypoglycaemia, perhaps because the latter displays data without the need to scan and is augmented by alerts for when the sensor glucose approaches hypoglycaemia, as detailed in a randomised parallel-group study [8].

Nonetheless, CGM technology is also accompanied by limitations, like skin irritation and pain, as assessed in children and pregnant women [9-12], sleep disruption due to discomfort associated with the position of the device [13], a constant reminder of having diabetes, overload of information and that the device is visible to others $[11,13,14]$. Furthermore, it is important to note that if hypo- and hyperglycaemic symptoms are not in line with the sensor glucose value, a confirmatory self-monitored blood glucose (SMBG) should be performed.

A lag time between the glucose value in the vasculature and interstitial fluid does exist and, thus, influences sensor glucose measurement accuracy against blood glucose values [15]. Moreover, other physiological changes during exercise, such as alterations in blood flow rate, body temperature and body acidity, can theoretically have an impact on interstitial glucosesensing accuracy [15], though the degree of impact of these factors is unknown on an individual basis. Thus, when assessing the accuracy of different interstitial glucose monitoring systems vs reference glucose, which is usually assessed by a median or mean absolute relative difference (MARD), a part of the difference should be interpreted as lag time rather than inaccuracy, as shown in a secondary outcome analysis of an experimental study [16]. Additionally, other factors, like local metabolic rate, sensor site [17], exercise type [18, 19], vasoconstriction [20], potential interference with medications [21], the direction of glucose rate of change $[22,23]$ and baseline glucose level may influence lag time [15]. Also, the glucose concentration, per se, might have an impact on the sensor accuracy, as seen for isCGM, detailing a lower MARD for hyperglycaemia and higher MARD for hypoglycaemia, as shown by two experimental studies $[24,25]$. At rest, a lag time of $\sim 5 \mathrm{~min}$ is seen in healthy individuals [26], while, in situations of rapid glucose changes, it can increase to up to 12 $24 \mathrm{~min}$ or even longer during exercise, as seen in people with type 1 diabetes [22, 23, 27]. Depending on the CGM and isCGM device, the overall mean of all MARDs during different types of exercise in people with type 1 diabetes is $~ 13.63 \%$ (95\% CI 11.41\%, 15.84\%), as detailed in Fig. 1 [16-18, 22, 24, 25, 27-37]. However, more recent CGM and isCGM devices, not yet investigated for exercise, might have a lower MARD and enhanced performance.

\section{Methods used for group consensus}

Due to the growing popularity of CGM and isCGM technologies, this writing group produced modified and novel recommendations based on current evidence, consensus statements and position statements for people with type 1 diabetes around exercise (i.e. before, during and after). This writing group consists of exercise physiologists, sports scientists, diabetologists, endocrinologists, paediatric diabetologists, bioengineers and nutritionists. After performing one-on-one meetings with all members of the writing group, a first outline was written based on the members' recommendations, including defined work packages for the authors. Subsequently, two lead authors (OM and JKM) produced a manuscript and circulated it within the writing group for further discussions. A consensus meeting was held during the Advanced Technologies \& Treatments for Diabetes (ATTD) 2020 conference in Madrid, Spain, and consensus was obtained. A final version of the position statement was then sent to the writing group for additional discussion, comments and final edits. All authors approved the final manuscript.

\section{Data sources, searches and study selection}

The consensus group accepted the position statement on physical activity/exercise and diabetes, of the American Diabetes Association (ADA) [38], the consensus statement for exercise management in type 1 diabetes [39] and the International Society for Pediatric and Adolescent Diabetes (ISPAD) clinical practice consensus guidelines for exercise in children and 


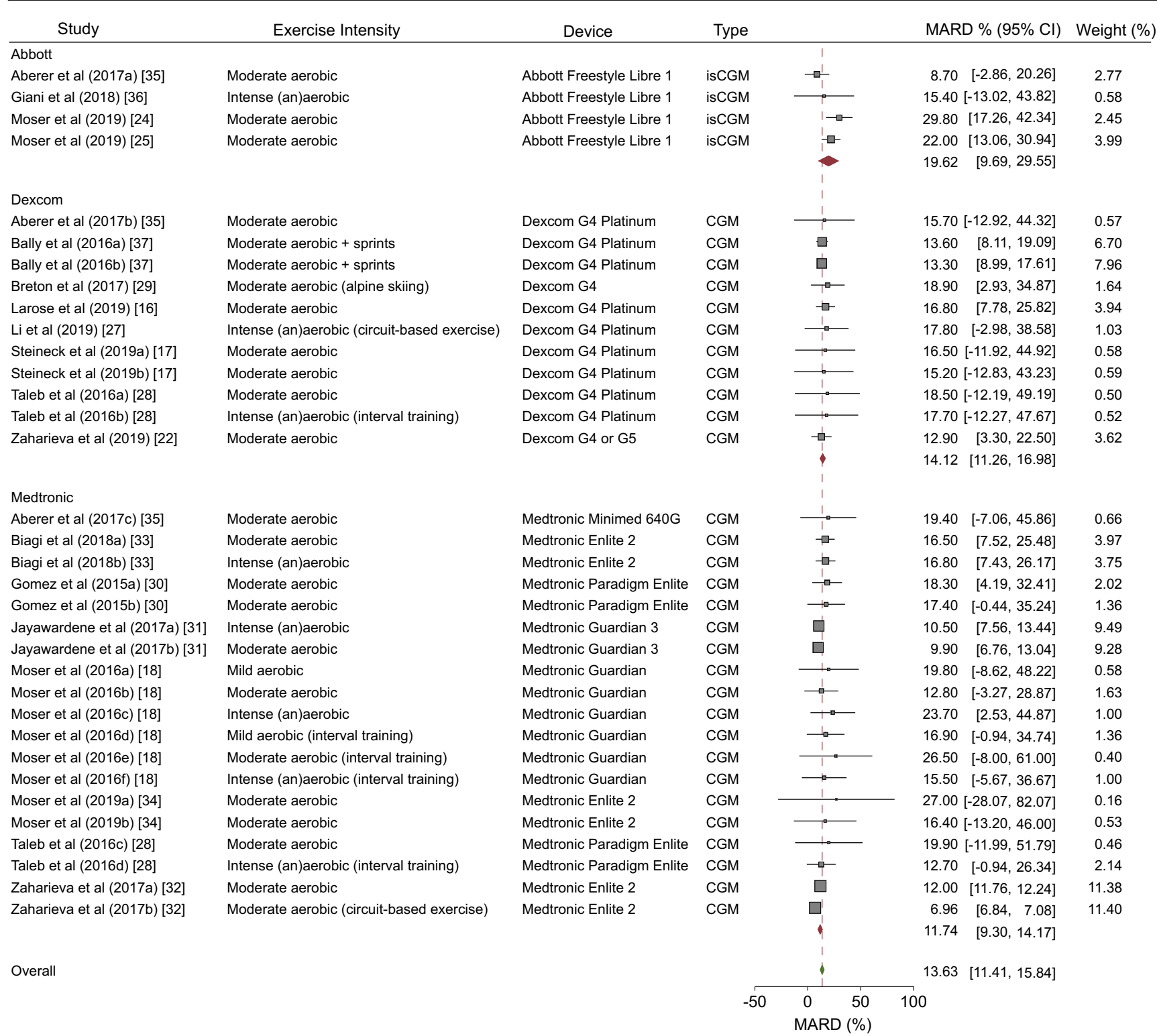

Fig. 1 MARD (\%) of current CGM and isCGM devices during exercise. MARD data are weighted for the number of participants and standard deviation of MARD for different manufacturers of all CGM and isCGM devices. The dashed line and the green diamond represent the MARD of all CGM and isCGM devices. Red diamonds represent the MARD for

adolescents with diabetes [40] as a starting point. Additionally, a systematic literature search was conducted by three independent researchers, using PubMed, EMBASE and the Cochrane Library for publications, on CGM and isCGM systems around exercise in people with type 1 diabetes between November and December 2019. Details on the keywords and the search strategy are available in electronic supplementary material (ESM) Tables 1-3. Original data investigating the performance of CGM and isCGM systems during exercise were used to produce a forest plot detailing the overall MARD between sensor glucose and reference glucose. Systematic reviews and meta-analyses were included as additional information for the use of CGM each specific company. Horizontal bars represent the 95\% CIs for the specific studies. All types of studies using CGM and/or isCGM during exercise in people with type 1 diabetes were included (the studies by Giani et al [36] and Breton et al [29] were performed in children and adolescents). This figure is available as part of a downloadable slideset

and isCGM around exercise. In addition, reference lists from each relevant publication were screened to identify additional articles pertinent to the topic. Papers were grouped per theme and the authors reviewed the evidence. Nevertheless, though evidence-based, the recommendations presented within this position statement are the opinions of the authors.

Level of evidence was set according to the Memorandum of Understanding (MOU) between the European Association for the Study of Diabetes (EASD) and the writing group of this position statement. Levels of evidence are, thus, categorised as: (Ia) evidence from meta-analysis of randomised controlled trials; ( $\mathrm{Ib}$ ) evidence from at least one 
randomised controlled trial; (IIa) evidence from at least one controlled study without randomisation; (IIb) evidence from at least one other type of quasi-experimental study; (III) evidence from non-experimental descriptive studies, such as comparative studies, correlation studies and case-control studies; or (IV) evidence from expert committee reports or opinions or clinical experience of respected authorities, or both. If recommendations are given within this position statement, the strength of those are expressed as: (A) directly based on category I evidence; (B) directly based on category II evidence or extrapolated recommendation from category I evidence; (C) directly based on category III evidence or extrapolated recommendation from category I or II evidence; (D) directly based on category IV evidence or extrapolated recommendation from category I, II or III.

\section{Therapy decisions from sensor glucose values and trend arrows for exercise}

Different groups of people with type 1 diabetes may require different glycaemic ranges in preparation for, during and after performing exercise when using CGM and isCGM systems, based on different position and consensus statements [40-43]. As discussed previously, CGM and isCGM devices may provide a different glucose reading compared with the actual SMBG, especially during exercise, and, thus, the sensor glucose value should be interpreted together with the corresponding trend arrow. Safe glycaemic ranges and specific carbohydrate consumption are recommended below, based on previous position and consensus statements [38] (D), [39] (D), [40] (D), and modified, based on experimental studies [44] (D), [45] (D) as well as on the experience of this writing group. Groups within the population of type 1 diabetes, based on different characteristics in this position statement, are defined as children and adolescents ( 6 to $<18$ years) and adults ( $\geq 18$ years) with type 1 diabetes. Additionally, further groups were defined based on the risk of hypoglycaemia, exercise experience and health status (older adults aged $\geq 65$ years). Since structured exercise training is less common in preschoolers, as observed in healthy individuals [46], the writing group is unable to provide specific recommendations due to the general lack of scientific evidence for this age group. Sustained hyperglycaemia (hours) and/or frequently occurring hypoglycaemia during exercise should be discussed between the individual and his/her healthcare professional team to develop individualised strategies that improve glycaemic control and support ongoing regular participation in exercise. The recommendations below serve as starting points and should be individualised.

Different glucose responses are evident depending on the type of exercise, as seen in different experimental studies [47-50]; mild-to-moderate aerobic exercise decreases glucose levels [51-53], whilst intense aerobic and anaerobic exercise and exercises with a load-profile similar to interval exercise stabilise [54] or increase glucose levels, as seen in various experimental studies [55-57]. Independent of the aforementioned groups (adults and children/adolescents), individuals who do not routinely exercise may face an increased risk of hypoglycaemia, as partially shown in a prospective observational study [58] (C). Additionally, IAH [59] (C), preceding episodes of hypoglycaemia [60] (B) and advanced age [58] (C) potentially increase the risk of hypoglycaemia during and after exercise. Therefore, the writing group recommends that the following groups can be categorised:

- Currently minimally exercising and/or high risk of hypoglycaemia

- Currently moderately exercising and/or moderate risk of hypoglycaemia

- Currently intensively exercising and/or low risk of hypoglycaemia

Assessment of exercise routine and risk of hypoglycaemia is recommended to be performed by a decision tree, modified based on a large-scale observational study [58] (C), and a recent consensus statement [41](D) (Fig. 2).

Older and/or frail adults with type 1 diabetes (aged $\geq 65$ years) may have a different health status that is reflected by different glycaemic goals based on $\mathrm{HbA}_{1 \mathrm{c}}$ and time in range (TIR), as discussed by recent consensus and position statements [41, 43]. In general, for this group, exercise is recommended to be performed 2-3 times per week as discussed by a position statement [38] (D). However, older people with type 1 diabetes are at an increased risk of severe hypoglycaemia around physical activity and exercise [58] (C). Considering this, higher glycaemic targets can be recommended for exercise based on patient characteristics and health status, to lower the risk of hypoglycaemia. Therefore, exercise can also be recommended for older adults with few coexisting chronic illnesses and intact cognitive and functional status, and for older adults with coexisting chronic illnesses or two or more instrumental activities-of-daily-living (ADL) impairments or mild-to-moderate cognitive impairment [61] (D). For older adults with very complex and poor health status, the possibility to perform exercise should be evaluated on a case-by-case basis [61] (D).

Recommendations for exercise based on habitual physical activity, risk of hypoglycaemia and health status (older and/or frail people with type 1 diabetes) should follow a more conservative strategy, which enables the avoidance of exerciseinduced glycaemic excursions. If a person is exercising more routinely and/or has a lower risk of hypoglycaemia over a period of 3 months, then the glycaemic upper and lower thresholds for carbohydrate consumption might be adjusted. Furthermore, in the following sections, generic trend arrows are given independently of the device used. 


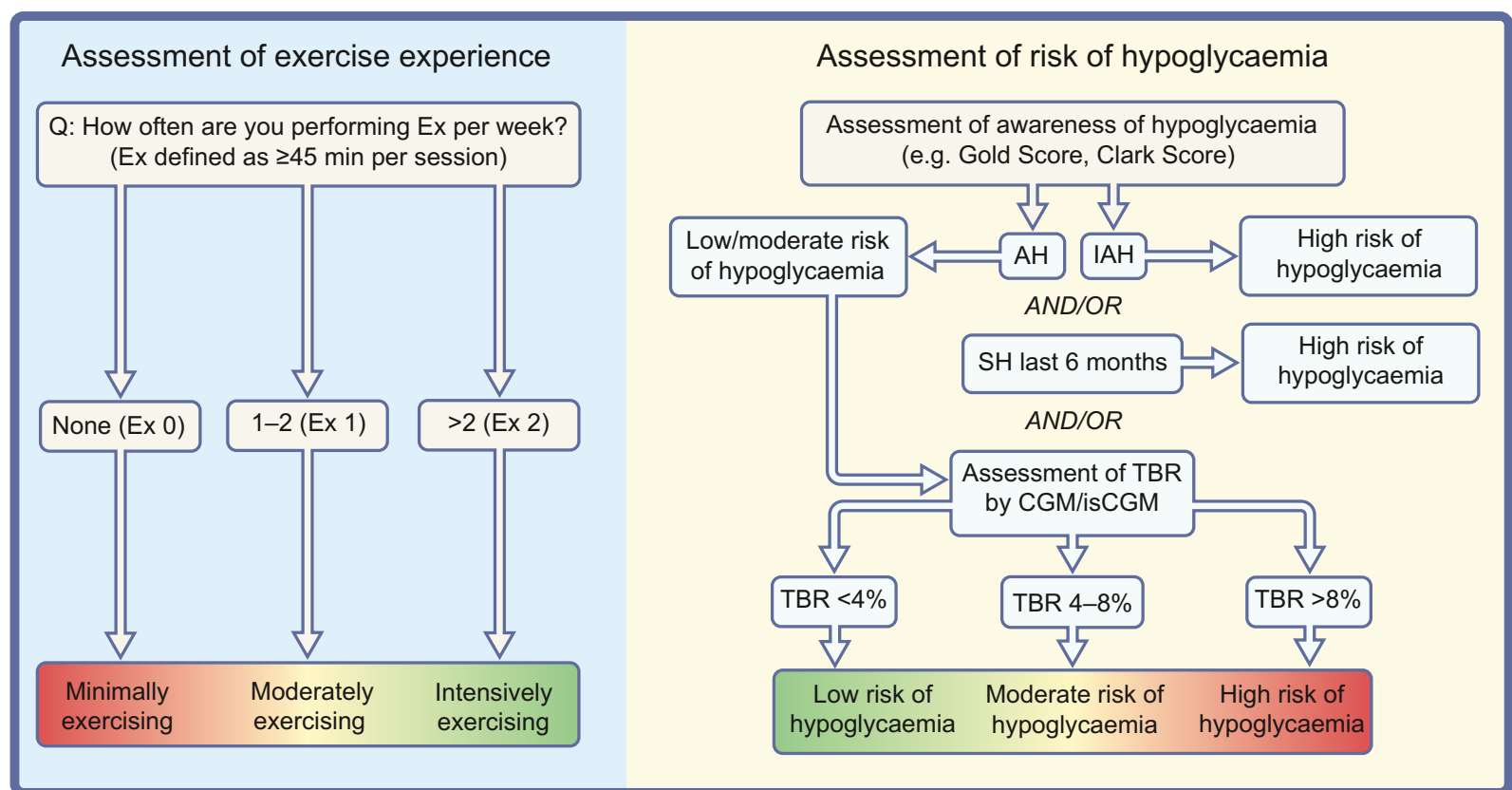

Fig. 2 Assessment of exercise experience and risk of hypoglycaemia. Exercise (Ex) represents how often people with type 1 diabetes are exercising with a duration $\geq 45 \mathrm{~min}$ per session per week. Assessment of risk of hypoglycaemia should be based on scoring systems for being aware of hypoglycaemia $(\mathrm{AH})$ or showing IAH. In addition, if the scoring system reveals $\mathrm{AH}$, the time below range (TBR; $<3.9 \mathrm{mmol} / \mathrm{l},<70 \mathrm{mg} / \mathrm{dl}$ ) over the last 3 months should be evaluated to detail the degree of awareness. Furthermore, if an episode of severe hypoglycaemia (SH) occurred within the last 6 months, then there might be a high risk of hypoglycaemia during exercise. This figure is available as part of a downloadable slideset

\section{Adults with type 1 diabetes}

CGM and isCGM systems can be used as effective tools to help indicate when carbohydrate intake should be initiated to prevent or treat hypoglycaemia during prolonged exercise, as seen in experimental studies in children and adolescents with type 1 diabetes [44, 45]. However, the significant lag time in these technologies should be taken into consideration when using them to determine when to consume carbohydrates [27]. Furthermore, isCGM requires frequent scanning since no automatic alerts are available for the first-generation device, as discussed in a narrative review [62]. For adults with type 1 diabetes, the following recommendations are given regarding the glycaemic thresholds below which carbohydrates might be consumed [38] (D), [39] (D), [40] (D), [44] (D), [45] (D):

- $\quad<7.0 \mathrm{mmol} / \mathrm{l}(<126 \mathrm{mg} / \mathrm{dl})$ for adults with type 1 diabetes, intensively exercising and/or with low risk of hypoglycaemia

- $<8.0 \mathrm{mmol} / 1$ ( $<145 \mathrm{mg} / \mathrm{dl})$ for adults with type 1 diabetes, moderately exercising and/or with moderate risk of hypoglycaemia, or for older adults with coexisting chronic illnesses and intact cognitive and functional status

- $\quad<9.0 \mathrm{mmol} / \mathrm{l}(<161 \mathrm{mg} / \mathrm{dl})$ for adults with type 1 diabetes, minimally exercising and/or with high risk of hypoglycaemia, or for older adults with coexisting chronic illnesses or two or more instrumental ADL impairments or mild-to-moderate cognitive impairment.
To lower the risk of hypoglycaemia during prolonged exercise, exercise should be initiated when mealtime insulin levels are low or about $90 \mathrm{~min}$ after the last carbohydraterich meal with a reduction in mealtime insulin [38] (D), [39] (D). However, to achieve beneficial effects of exercise on overall glycaemic control, exaggerated bolus insulin dose reductions should be avoided, as discussed in a metaanalysis [63] (D).

Preparation in advance to exercise If a CGM or a secondgeneration isCGM device is used, hypoglycaemic alerts might be set at the highest possible alarm lower threshold at the onset of exercise, which is currently $5.6 \mathrm{mmol} / \mathrm{l}(100 \mathrm{mg} / \mathrm{dl})$ [22] (D). This elevated hypoglycaemia alert setting is in line with the expected delay between interstitial glucose and blood glucose when levels are dropping during prolonged exercise [22]. Importantly, for the second-generation isCGM device, an alert is only shown once and not repeated. Hyperglycaemic alerts can be set to $10.0 \mathrm{mmol} / \mathrm{l}(180 \mathrm{mg} / \mathrm{dl})$ or higher, to avoid alarm fatigue [64] (D). The rate-of-glucose-change alerts (dropping or rising) can be used to initiate an earlier action, such as a decrease or increase in basal insulin rate for those on continuous subcutaneous insulin infusion (CSII), or a change to glucose-rich or glucose-free fluids, depending on the direction of change. Thirty to $60 \mathrm{~min}$ prior to the start of prolonged aerobic exercise ( $>30 \mathrm{~min}$ ), to reduce hypoglycaemia risk, low glycaemic index carbohydrates can be consumed in those who do not reduce 
Table 1 Sensor glucose targets in advance of exercise in regard to different groups of people with type 1 diabetes

\begin{tabular}{|c|c|c|c|c|c|}
\hline \multicolumn{3}{|c|}{$\begin{array}{l}\text { Pre-exercise sensor glucose for } \\
\text { different groups in T1D }\end{array}$} & \multirow{2}{*}{$\begin{array}{l}\text { Trend } \\
\text { arrow }\end{array}$} & \multicolumn{2}{|c|}{ Action } \\
\hline $\begin{array}{c}\text { Ex } 2 \\
\text { and/or } \\
\text { low } \\
\text { hypo risk }\end{array}$ & $\begin{array}{c}\text { Ex } 1 \\
\text { and/or } \\
\text { moderate } \\
\text { hypo risk }^{\mathrm{a}}\end{array}$ & $\begin{array}{c}\text { Ex 0 } \\
\text { and/or } \\
\text { high } \\
\text { hypo risk }\end{array}$ & & $\begin{array}{l}\text { Increase in sensor } \\
\text { glucose expected }\end{array}$ & $\begin{array}{l}\text { Decrease in sensor } \\
\text { glucose expected }\end{array}$ \\
\hline \multicolumn{3}{|c|}{$\begin{array}{l}>15.0 \mathrm{mmol} / \mathrm{l}(>270 \mathrm{mg} / \mathrm{dl}) \\
\text { AND }>1.5 \mathrm{mmol} / \mathrm{l} \text { blood ketones }\end{array}$} & ヘતカン৬ & \multicolumn{2}{|c|}{$\begin{array}{c}\text { No Ex, } \\
\text { Insulin correction }\end{array}$} \\
\hline \multirow{3}{*}{\multicolumn{3}{|c|}{$\begin{array}{l}>15.0 \mathrm{mmol} / \mathrm{l}(>270 \mathrm{mg} / \mathrm{dl}) \\
\text { AND } \leq 1.5 \mathrm{mmol} / \mathrm{l} \text { blood ketones }\end{array}$}} & スト & $\begin{array}{l}\text { Consider insulin } \\
\text { correction } \\
\text { Can start AE }\end{array}$ & $\begin{array}{l}\text { Consider insulin } \\
\text { correction' } \\
\text { Can start all Ex }\end{array}$ \\
\hline & & & $\Rightarrow$ & $\begin{array}{l}\text { Consider insulin } \\
\text { correctionc, } \\
\text { Can start AE }\end{array}$ & $\begin{array}{l}\text { Consider insulin } \\
\text { correctionc, } \\
\text { Can start all Ex }\end{array}$ \\
\hline & & & $\boldsymbol{y} \downarrow$ & \multicolumn{2}{|c|}{ Can start all Ex } \\
\hline \multirow{3}{*}{$\begin{array}{c}10.1-15.0 \\
\mathrm{mmol} / \mathrm{l} \\
(181-270 \\
\mathrm{mg} / \mathrm{dl})\end{array}$} & \multirow{3}{*}{$\begin{array}{c}11.1-15.0 \\
\mathrm{mmol} / \mathrm{l} \\
(199-270 \\
\mathrm{mg} / \mathrm{dl})\end{array}$} & \multirow{3}{*}{$\begin{array}{c}12.1-15.0 \\
\mathrm{mmol} / \mathrm{l} \\
(217-270 \\
\mathrm{mg} / \mathrm{dl})\end{array}$} & スヤ & \multicolumn{2}{|c|}{$\begin{array}{l}\text { Can start AE } \\
\text { Consider insulin correction for RT, } \mathrm{HIT}^{\mathrm{c}}\end{array}$} \\
\hline & & & $\rightarrow$ & $\begin{array}{l}\text { Can start all Ex, } \\
\text { Consider insulin } \\
\text { correction }^{c}\end{array}$ & Can start all Ex \\
\hline & & & $\boldsymbol{y} \Downarrow$ & Cans & all Ex \\
\hline \multirow{3}{*}{$\begin{array}{c}7.0-10.0 \\
\mathrm{mmol} / \mathrm{l} \\
(126-180 \\
\mathrm{mg} / \mathrm{dl})\end{array}$} & \multirow{3}{*}{$\begin{array}{c}8.0-11.0 \\
\mathrm{mmol} / \mathrm{l} \\
(145-198 \\
\mathrm{mg} / \mathrm{dl})\end{array}$} & \multirow{3}{*}{$\begin{array}{c}9.0-12.0 \\
\mathrm{mmol} / \mathrm{l} \\
(162-216 \\
\mathrm{mg} / \mathrm{dl})\end{array}$} & スィ & \multirow{2}{*}{\multicolumn{2}{|c|}{ Can start all Ex }} \\
\hline & & & $\rightarrow$ & & \\
\hline & & & צע & Can start all Ex & $\begin{array}{l}\sim 15 \mathrm{~g} \mathrm{CHO}, \\
\text { Can start all Ex }\end{array}$ \\
\hline \multirow{4}{*}{$\begin{array}{c}5.0-6.9 \\
\mathrm{mmol} / \mathrm{l} \\
(90-125 \\
\mathrm{mg} / \mathrm{dl})\end{array}$} & \multirow{4}{*}{$\begin{array}{c}5.0-7.9 \\
\mathrm{mmol} / \mathrm{l} \\
(90-144 \\
\mathrm{mg} / \mathrm{dl})\end{array}$} & \multirow{4}{*}{$\begin{array}{c}5.0-8.9 \\
\mathrm{mmol} / \mathrm{l} \\
(90-161 \\
\mathrm{mg} / \mathrm{dl})\end{array}$} & スヤ & Can start all Ex & $\begin{array}{l}\sim 15 \mathrm{~g} \mathrm{CHO}, \\
\text { Can start all Ex }\end{array}$ \\
\hline & & & $\rightarrow$ & $\begin{array}{l}\sim 10 \mathrm{~g} \mathrm{CHO}, \\
\text { Can start all Ex }\end{array}$ & $\begin{array}{l}\sim 20 \mathrm{~g} \mathrm{CHO}, \\
\text { Can start all Ex }\end{array}$ \\
\hline & & & y & $\begin{array}{l}\sim 15 \mathrm{~g} \mathrm{CHO} \\
\text { Delay all Ex }\end{array}$ & $\begin{array}{l}\sim 25 \mathrm{~g} \mathrm{CHO} \\
\text { Delay all Ex }\end{array}$ \\
\hline & & & $\downarrow$ & $\begin{array}{l}20 \text { g CHO, }^{\text {Celay all Ex }} \\
\text { Del }\end{array}$ & $\begin{array}{l}\sim 30 \mathrm{~g} \mathrm{CHO} \\
\text { Delay all Ex }\end{array}$ \\
\hline \multirow{5}{*}{\multicolumn{3}{|c|}{$\begin{array}{l}3.9-4.9 \mathrm{mmol} / \mathrm{l} \\
(70-89 \mathrm{mg} / \mathrm{dl})\end{array}$}} & $\uparrow$ & $\begin{array}{l}\sim 10 \mathrm{~g} \mathrm{CHO}, \\
\text { Can start all Ex }\end{array}$ & $\begin{array}{l}\sim 20 \mathrm{~g} \mathrm{CHO} \\
\text { Delay all Ex }\end{array}$ \\
\hline & & & $\pi$ & $\begin{array}{l}\sim 15 \mathrm{~g} \mathrm{CHO} \\
\text { Delay all Ex }\end{array}$ & $\begin{array}{l}\sim 25 \mathrm{~g} \mathrm{CHO} \\
\text { Delay all Ex }\end{array}$ \\
\hline & & & $\rightarrow$ & $\begin{array}{l}20 \mathrm{~g} \mathrm{CHO}^{\mathrm{CH}} \\
\text { Delay all Ex}\end{array}$ & $\begin{array}{l}\sim 30 \mathrm{~g} \mathrm{CHO}^{d} \\
\text { Delay all Ex }\end{array}$ \\
\hline & & & y & $\begin{array}{l}\sim 25 \mathrm{~g} \mathrm{CHO}^{\mathrm{e}} \\
\text { Delay all Ex }\end{array}$ & $\begin{array}{l}\sim 35 \mathrm{~g} \mathrm{CHO} \\
\text { Delay all } \mathrm{Ex}^{\mathrm{d}}\end{array}$ \\
\hline & & & $\downarrow$ & $\begin{array}{l}\text { Individual amount } \\
\text { CHO ingestion, } \\
\text { Delay all Ex }\end{array}$ & $\begin{array}{l}\text { Individual amount } \\
\text { CHO ingestion, } \\
\text { Delay all Ex }\end{array}$ \\
\hline \multicolumn{3}{|c|}{$\begin{array}{l}<3.9 \mathrm{mmol} / \mathrm{l} \\
(<70 \mathrm{mg} / \mathrm{dl})\end{array}$} & & \multicolumn{2}{|c|}{$\begin{array}{l}\text { Individual amount } \mathrm{CHO} \text { ingestion, } \\
\text { Delay all Ex }\end{array}$} \\
\hline
\end{tabular}

Sensor glucose targets are detailed for the following groups in type 1 diabetes (T1D): intensively exercising and/or low risk of hypoglycaemia (Ex 2); moderately exercising and/or moderate risk of hypoglycaemia (Ex 1); minimally exercising and/or high risk of hypoglycaemia (Ex 0)

${ }^{a}$ Recommendation for older adults with coexisting chronic illnesses and intact cognitive and functional status

${ }^{\mathrm{b}}$ Recommendation for older adults with coexisting chronic illnesses or two or more instrumental ADL impairments or mild-to-moderate cognitive impairment ${ }^{\mathrm{c}} 50 \%$ of regular insulin correction factor when sensor glucose is close to the upper threshold

${ }^{\mathrm{d}}$ Delay exercise until reaching at least $5.0 \mathrm{mmol} / \mathrm{l}(90 \mathrm{mg} / \mathrm{dl})$ and $\rightarrow, \boldsymbol{\gamma}$, or $\boldsymbol{\uparrow}$

${ }^{\mathrm{e}}$ Delay exercise until reaching at least $3.9-4.9 \mathrm{mmol} / \mathrm{l}(70-89 \mathrm{mg} / \mathrm{dl})$ and $\boldsymbol{\uparrow}$

${ }^{\mathrm{f}}$ Delay exercise until reaching a sensor glucose of 3.9-4.9 mmol/1 (70-89 mg/dl) with an $\mathbf{\uparrow}$ arrow if an increase in sensor glucose is expected during exercise, or delay exercise until reaching at least $5.0 \mathrm{mmol} / 1(90 \mathrm{mg} / \mathrm{dl})$ and $\boldsymbol{\rightarrow}, \boldsymbol{\lambda}$, or $\boldsymbol{\uparrow}$ if a decrease in sensor glucose during exercise is expected

When reaching the required sensor glucose level to start exercise, only consume carbohydrates again when trend arrow is starting to decrease

These recommendations are not applicable to hybrid closed-loop systems

Green shading, no/minimal action required; light-yellow shading, minimal/moderate action required; dark-yellow shading, moderate/intense action required; red shading, no/delay exercise

AE, mild-to-moderate intensity aerobic exercise; $\mathrm{CHO}$, carbohydrate; Ex, exercise; HIT, high-intensity training; hypo, hypoglycaemia; RT, resistance training 
Table 2 Sensor glucose targets during exercise in regard to different groups of people with type 1 diabetes

\begin{tabular}{|c|c|c|c|c|c|}
\hline \multicolumn{3}{|c|}{$\begin{array}{l}\text { During exercise sensor glucose for different } \\
\text { groups in T1D }\end{array}$} & \multirow{2}{*}{$\begin{array}{l}\text { Trend } \\
\text { arrow } \\
\text { Direction }\end{array}$} & \multicolumn{2}{|c|}{ Action } \\
\hline $\begin{array}{l}\text { Ex } 2 \text { and/or low } \\
\text { hypo risk }\end{array}$ & $\begin{array}{c}\text { Ex } 1 \\
\text { and/or } \\
\text { moderate } \\
\text { hypo risk }^{\mathrm{a}}\end{array}$ & $\begin{array}{c}\text { Ex 0 } \\
\text { and/or } \\
\text { high } \\
\text { hypo risk }^{\text {b }}\end{array}$ & & $\begin{array}{l}\text { Increase in sensor } \\
\text { glucose expected }\end{array}$ & $\begin{array}{l}\text { Decrease in sensor } \\
\text { glucose expected }\end{array}$ \\
\hline \multicolumn{3}{|c|}{$\begin{array}{c}>15.0 \mathrm{mmol} / \mathrm{l}(>270 \mathrm{mg} / \mathrm{dl}) \\
\text { AND }>1.5 \mathrm{mmol} / \mathrm{l} \text { blood ketones }\end{array}$} & ヘフフンレ & \multicolumn{2}{|c|}{$\begin{array}{c}\text { Stop Ex, } \\
\text { Consider insulin correction, } \\
\text { No restart of Ex }\end{array}$} \\
\hline \multirow{3}{*}{\multicolumn{3}{|c|}{$\begin{array}{l}>15.0 \mathrm{mmol} / \mathrm{l} \text { (>270 mg/dl) } \\
\text { AND } \leq 1.5 \mathrm{mmol} / \mathrm{l} \text { blood ketones }\end{array}$}} & スト & $\begin{array}{l}\text { Consider insulin } \\
\text { correction }^{c} \text {, } \\
\text { Proceed all Ex }\end{array}$ & $\begin{array}{l}\text { Proceed all Ex, } \\
\text { Consider AE }\end{array}$ \\
\hline & & & $\rightarrow$ & $\begin{array}{l}\text { Consider insulin } \\
\text { correctionc, }^{c} \\
\text { Proceed all Ex }\end{array}$ & Proceed all Ex \\
\hline & & & $\boldsymbol{y} \Downarrow$ & \multicolumn{2}{|c|}{ Proceed all Ex } \\
\hline \multirow{3}{*}{$\begin{array}{c}10.1-15.0 \\
\mathrm{mmol} / \mathrm{l} \\
(181-270 \\
\mathrm{mg} / \mathrm{dl})\end{array}$} & \multirow{3}{*}{$\begin{array}{c}11.1-15.0 \\
\mathrm{mmol} / \mathrm{l} \\
(199-270 \\
\mathrm{mg} / \mathrm{dl})\end{array}$} & \multirow{3}{*}{$\begin{array}{c}12.1-15.0 \\
\mathrm{mmol} / \mathrm{l} \\
(217-270 \\
\mathrm{mg} / \mathrm{dl})\end{array}$} & クト & \multirow{2}{*}{$\begin{array}{l}\text { Proceed all Ex, } \\
\text { Consider insulin } \\
\text { correction }^{c}\end{array}$} & \multirow[b]{2}{*}{ Proceed all Ex } \\
\hline & & & $\rightarrow$ & & \\
\hline & & & $\boldsymbol{y} \downarrow$ & \multicolumn{2}{|c|}{ Proceed all Ex } \\
\hline \multirow{3}{*}{$\begin{array}{c}7.0-10.0 \\
\mathrm{mmol} / \mathrm{l} \\
(126-180 \\
\mathrm{mg} / \mathrm{dl})\end{array}$} & \multirow{3}{*}{$\begin{array}{c}8.0-11.0 \\
\mathrm{mmol} / \mathrm{l}) \\
(145-198 \\
\mathrm{mg} / \mathrm{dl})\end{array}$} & \multirow{3}{*}{$\begin{array}{c}9.0-12.0 \\
\mathrm{mmol} / \mathrm{l} \\
(162-216 \\
\mathrm{mg} / \mathrm{dl})\end{array}$} & スト & \multirow{3}{*}{\multicolumn{2}{|c|}{ Proceed all Ex }} \\
\hline & & & $\Rightarrow$ & & \\
\hline & & & עע & & \\
\hline \multirow{4}{*}{$\begin{array}{c}<7.0 \\
\mathrm{mmol} / \mathrm{l} \\
(<126 \\
\mathrm{mg} / \mathrm{dl})\end{array}$} & \multirow{4}{*}{$\begin{array}{c}<8.0 \\
\mathrm{mmol} / \mathrm{l} \\
(<145 \\
\mathrm{mg} / \mathrm{dl})\end{array}$} & \multirow{4}{*}{$\begin{array}{c}<9.0 \\
\mathrm{mmol} / \mathrm{l} \\
(<162 \\
\mathrm{mg} / \mathrm{dl})\end{array}$} & スト & \multicolumn{2}{|c|}{ Proceed all Ex } \\
\hline & & & $\Rightarrow$ & $\begin{array}{l}\sim 10 \mathrm{~g} \mathrm{CHO}^{\mathrm{C}} \\
\text { Proceed all Ex }\end{array}$ & $\begin{array}{l}\sim 15 \mathrm{~g} \mathrm{CHO} \\
\text { Proceed all Ex }\end{array}$ \\
\hline & & & y & $\begin{array}{l}\sim 15 \mathrm{~g} \mathrm{CHO}, \\
\text { Proceed all Ex }\end{array}$ & $\begin{array}{l}\sim 25 \mathrm{~g} \mathrm{CHO}, \\
\text { Proceed all Ex }\end{array}$ \\
\hline & & & $\downarrow$ & $\begin{array}{l}\sim 20 \mathrm{~g} \mathrm{CHO} \\
\text { Proceed all Ex }\end{array}$ & $\begin{array}{l}\sim 35 \mathrm{~g} \mathrm{CHO} \\
\text { Proceed all Ex }\end{array}$ \\
\hline \multirow{5}{*}{\multicolumn{3}{|c|}{$\begin{array}{l}<3.9 \mathrm{mmol} / \mathrm{l} \\
(<70 \mathrm{mg} / \mathrm{dl})\end{array}$}} & $\uparrow$ & \multirow{5}{*}{\multicolumn{2}{|c|}{$\begin{array}{c}\text { Stop all Ex, } \\
\text { Consider confirmatory SMBG, } \\
\text { Individual amount CHO ingestion, } \\
\text { Restart of all Ex possible }{ }^{\mathrm{e}}\end{array}$}} \\
\hline & & & $\pi$ & & \\
\hline & & & $\rightarrow$ & & \\
\hline & & & $y$ & & \\
\hline & & & $\downarrow$ & & \\
\hline \multicolumn{3}{|c|}{$\begin{array}{l}<3.0 \mathrm{mmol} / \mathrm{l} \\
(<54 \mathrm{mg} / \mathrm{dl})\end{array}$} & \multicolumn{3}{|c|}{$\begin{array}{c}\text { Stop all Ex, } \\
\text { Confirmatory SMBG, } \\
\text { Individual amount } \mathrm{CHO} \text { ingestion, } \\
\text { No restart of Ex }\end{array}$} \\
\hline
\end{tabular}

Sensor glucose targets are detailed for the following groups in type 1 diabetes (T1D): intensively exercising and/or low risk of hypoglycaemia (Ex 2); moderately exercising and/or moderate risk of hypoglycaemia (Ex 1); minimally exercising and/or high risk of hypoglycaemia (Ex 0)

${ }^{a}$ Recommendation for older adults with coexisting chronic illnesses and intact cognitive and functional status

${ }^{b}$ Recommendation for older adults with coexisting chronic illnesses or two or more instrumental ADL impairments or mild-to-moderate cognitive impairment

${ }^{\mathrm{c}} 50 \%$ of the regular insulin correction factor

${ }^{\mathrm{d}}$ Check sensor glucose at least $30 \mathrm{~min}$ after carbohydrate consumption and repeat treatment if required

${ }^{\mathrm{e}}$ Restart exercise when reaching sensor glucose levels of at least $4.4 \mathrm{mmol} / \mathrm{l}(80 \mathrm{mg} / \mathrm{dl})$ and $\rightarrow$, $\boldsymbol{\nearrow}$ or $\boldsymbol{\uparrow}$

When reaching the required sensor glucose level during exercise, only consume carbohydrates again when trend arrow is starting to decrease

These recommendations are not applicable to hybrid closed-loop systems

Green shading, no/minimal action required; light-yellow shading, minimal/moderate action required; dark-yellow shading, moderate/intense action required; red shading, stop exercise

$\mathrm{AE}$, mild-to-moderate intensity aerobic exercise; $\mathrm{CHO}$, carbohydrate; Ex, exercise; hypo, hypoglycaemia 
Table 3 Sensor glucose targets for carbohydrate consumption during the post-exercise phase, including the nocturnal post-exercise phase if exercise was performed in the late afternoon/evening

\begin{tabular}{|c|c|c|c|c|}
\hline \multicolumn{3}{|c|}{$\begin{array}{l}\text { Post-exercise sensor glucose, including nocturnal phase, } \\
\text { for different groups in T1D }\end{array}$} & \multirow{2}{*}{$\begin{array}{l}\begin{array}{c}\text { Trend } \\
\text { arrow }\end{array} \\
\text { Direction }\end{array}$} & \multirow{2}{*}{$\begin{array}{l}\text { Action } \\
\mathrm{CHO}\end{array}$} \\
\hline $\begin{array}{l}\text { Ex } 2 \text { and/or low } \\
\text { hypo risk }\end{array}$ & $\begin{array}{c}\text { Ex } 1 \text { and/or } \\
\text { moderate hypo risk }\end{array}$ & $\begin{array}{c}\text { Ex } 0 \text { and/or } \\
\text { high hypo risk }\end{array}$ & & \\
\hline \multirow{4}{*}{$\begin{array}{l}<4.4 \mathrm{mmol} / \mathrm{l} \\
(<80 \mathrm{mg} / \mathrm{dl})\end{array}$} & \multirow{4}{*}{$\begin{array}{l}<5.0 \mathrm{mmol} / \mathrm{l} \\
(<90 \mathrm{mg} / \mathrm{dl})\end{array}$} & \multirow{4}{*}{$\begin{array}{l}<5.6 \mathrm{mmol} / \mathrm{l} \\
(<100 \mathrm{mg} / \mathrm{dl})\end{array}$} & $\begin{array}{l}\uparrow \\
\pi\end{array}$ & $\mathrm{No} \mathrm{CHO}$ \\
\hline & & & $\Rightarrow$ & $\sim 10 \mathrm{~g} \mathrm{CHO}$ \\
\hline & & & y & $\sim 15 \mathrm{~g} \mathrm{CHO}$ \\
\hline & & & $\downarrow$ & $\begin{array}{l}\text { Individual amount } \\
\mathrm{CHO} \text { ingestion }\end{array}$ \\
\hline
\end{tabular}

Sensor glucose thresholds for treatments are detailed for the following groups in type 1 diabetes (T1D): intensively exercising and/or low risk of hypoglycaemia (Ex 2); moderately exercising and/or moderate risk of hypoglycaemia (Ex 1); minimally exercising and/or high risk of hypoglycaemia (Ex 0)

${ }^{a}$ Recommendation for older adults with coexisting chronic illnesses and intact cognitive and functional status

${ }^{\mathrm{b}}$ Recommendation for older adults with coexisting chronic illnesses or two or more instrumental ADL impairments or mild-to-moderate cognitive impairment

If an insulin correction is applied due to high sensor glucose levels, then the regular correction factor might be reduced by up to $50 \%$

Check sensor glucose at least 30 min after carbohydrate consumption and repeat treatment if required

These recommendations are not applicable to hybrid closed-loop systems

The intensity of yellow shading indicates the level of action required: lighter yellow shading indicates that minimal/moderate action is required, while darker yellow shading indicates that moderate/intense action is required

$\mathrm{CHO}$, carbohydrate; Ex, exercise; hypo, hypoglycaemia

insulin dose, aiming to achieve pre-exercise sensor glucose targets. A detailed description of pre-exercise sensor glucose levels, trend arrows and consumption of carbohydrates is shown in Table 1 based on position and consensus statements and experimental studies [38] (D), [39] (D), [40] (D), [44] (D), [45] (D).

During exercise Independent of the type of exercise, the target sensor glucose ranges should be between $5.0 \mathrm{mmol} / \mathrm{l}$ and $10.0 \mathrm{mmol} / 1(90 \mathrm{mg} / \mathrm{dl}$ and $180 \mathrm{mg} / \mathrm{dl})$ and, ideally, between $7.0 \mathrm{mmol} / \mathrm{l}$ and $10.0 \mathrm{mmol} / \mathrm{l}(126 \mathrm{mg} / \mathrm{dl}$ and $180 \mathrm{mg} / \mathrm{dl})$ for prolonged aerobic exercise for the majority of adults with type 1 diabetes, and slightly higher for those with an increased risk of hypoglycaemia (Table 2) [38] (D), [39] (D). If sensor glucose is expected to increase, as often seen in people performing fasted high-intensity interval training [55, 56], resistance training $[49,65,66]$ and, also, in training above the anaerobic threshold [67], then an insulin correction can be administered at the onset of, as well as during exercise (50\% of typical correction factor) [68] (D), [69] (D).

For safety reasons, the exercise should be suspended, at least temporarily, if the sensor glucose level reaches $<3.9 \mathrm{mmol} / 1$ ( $<70 \mathrm{mg} / \mathrm{dl}$ ) and oral carbohydrates should be consumed [70] (D). Furthermore, at this lower threshold, a confirmatory SMBG might be performed to confirm the sensor glucose level. After reaching a sensor glucose level close to $4.4 \mathrm{mmol} / \mathrm{l}(80 \mathrm{mg} / \mathrm{dl})$, accompanied by a horizontal/upward trend arrow, exercise can be restarted. Many CGM systems provide a hypoglycaemia prediction alert. If the sensor glucose level is predicted to reach $<3.0 \mathrm{mmol} / 1(<54 \mathrm{mg} / \mathrm{dl})$, then fast-acting oral carbohydrates should be consumed immediately. If sensor glucose drops below $3.0 \mathrm{mmol} / \mathrm{l}(54 \mathrm{mg} / \mathrm{dl})$ then exercise should not be restarted. During exercise, fast-acting liquid carbohydrates should be consumed consisting primarily of glucose (dextrose) or a mixture of glucose/fructose, as discussed in narrative reviews [71] (D), [72] (D). A read or scan from the CGM or isCGM system might be performed every 15-30 min, if feasible, during exercise to ensure early and appropriate treatment against hypoor hyperglycaemia, and to assess the appropriateness of strategies to prevent dysglycaemia. With CGM, alerts could also be activated regarding the rate of change in glucose, providing the user with valuable information. For the majority of adults with type 1 diabetes who are at a low risk of hypoglycaemia, at a glycaemic threshold of $7.0 \mathrm{mmol} / \mathrm{l}(126 \mathrm{mg} / \mathrm{dl})$ accompanied by a horizontal trend arrow, 10-15 g of carbohydrates should be consumed; $15-25 \mathrm{~g}$ carbohydrates should be consumed immediately if accompanied by a (slightly) downward trend arrow; 20-35 g of carbohydrates should be consumed if accompanied with a downward trending arrow (Table 2) [38] (D), [39] (D), [40] (D), [44] (D), [45] (D). Carbohydrates should be consumed regularly (e.g., every 15 to $20 \mathrm{~min}$ ) when reaching the lower glycaemic threshold, and carbohydrate supplementation should be repeated if sensor glucose is not rising according to the trend arrows within $30 \mathrm{~min}$. These carbohydrate recommendations should be used as a guidance and personalised based on 
Table 4 General insulin therapy and carbohydrate recommendations for exercise in children and adolescents with type 1 diabetes

\begin{tabular}{|c|c|c|}
\hline Type of therapy & $\begin{array}{l}\text { Type/intensity of exercise } \\
\text { Duration } 30-45 \mathrm{~min}\end{array}$ & $\begin{array}{l}\text { Type/intensity of exercise } \\
\text { Duration }>45 \mathrm{~min}\end{array}$ \\
\hline $\begin{array}{l}\text { MDI/CSII: mealtime } \\
\text { bolus insulin dose } \\
\text { reduction }\end{array}$ & $\begin{array}{l}-25 \% \text { for mild aerobic } \\
-50 \% \text { for moderate aerobic } \\
-50 \% \text { for intense aerobic } \\
-25 \% \text { for mixed aerobic/anaerobic } \\
\text { Up to }-50 \% \text { post exercise }\end{array}$ & $\begin{array}{l}-50 \% \text { for mild aerobic } \\
-75 \% \text { for moderate aerobic } \\
-75 \% \text { for intense aerobic } \\
-50 \% \text { for mixed aerobic/anaerobic } \\
\text { Up to }-50 \% \text { post exercise }\end{array}$ \\
\hline MDI: basal insulina & $\begin{array}{l}-20 \% \text { for evening/late afternoon } \\
\text { exercise }\end{array}$ & $\begin{array}{l}-20 \% \text { for evening/late afternoon } \\
\text { exercise } \\
-30 \text { to }-50 \% \text { for all-day/unusual } \\
\text { activities }^{\mathrm{a}}\end{array}$ \\
\hline CSII: basal insulin rate & $\begin{array}{l}\text { Up to }-50 \% 90 \text { min pre exercise } \\
\text { Insulin pump suspension (<60 min) } \\
-20 \% \text { for post-exercise night time }\end{array}$ & $\begin{array}{l}\text { Up to }-80 \% 90 \text { min pre exercise } \\
\text { Insulin pump suspension (<60 min) } \\
-20 \% \text { for post-exercise night time }{ }^{b}\end{array}$ \\
\hline General $\mathrm{CHO}$ intake ${ }^{\mathrm{c}}$ & $\begin{array}{l}\text { 10-15 g CHO depending on IOB and } \\
\text { sensor glucose level } \\
1.5 \mathrm{~g} \mathrm{CHO} \text { per } \mathrm{kg} \mathrm{BW} / \mathrm{h} \text { for intense } \\
\text { exercise (regular IOB) } \\
0.25 \mathrm{~g} \mathrm{CHO} \mathrm{per} \mathrm{kg} \mathrm{BW} / \mathrm{h} \text { for intense } \\
\text { exercise (less IOB) } \\
0.4 \mathrm{~g} \mathrm{CHO} / \mathrm{kg} \mathrm{BW} \text { pre-bed snack for } \\
\text { evening/late afternoon exercise }\end{array}$ & $\begin{array}{l}\text { 10-15 g CHO depending on IOB and } \\
\text { sensor glucose level } \\
1.5 \mathrm{~g} \mathrm{CHO} \text { per kg BW/h for intense } \\
\text { and/or long-lasting exercise (regular } \\
\text { IOB) } \\
0.25 \mathrm{~g} \mathrm{CHO} \text { per kg BW/h for intense } \\
\text { exercise (less IOB) } \\
0.4 \mathrm{~g} \mathrm{CHO/kg} \mathrm{BW} \mathrm{pre-bed} \mathrm{snack} \mathrm{for} \\
\text { evening/late afternoon exercise }\end{array}$ \\
\hline
\end{tabular}

${ }^{\text {a }}$ Basal insulin dose might be reduced the day prior and on the day of all-day exercise

${ }^{\mathrm{b}}$ Basal insulin rate might be reduced by $20 \%$ before bedtime if late afternoon/evening exercise was performed, depending on the duration and intensity of exercise

${ }^{\mathrm{c}}$ Regular IOB, no/little insulin reduction has been performed; less IOB, moderate/high insulin reduction has been performed

BW, body weight; $\mathrm{CHO}$, carbohydrates; CSII, continuous subcutaneous insulin infusion; IOB, insulin on board; MDI, multiple daily injections

individual glucose responses to exercise. Carbohydrate consumption for endurance performance in individuals with type 1 diabetes is similar to the carbohydrate needs in healthy individuals (30-80 g carbohydrates per $\mathrm{h}$ ), typically reflecting the physiological and/or performance demands of exercise [73] (A). A lower carbohydrate intake can be achieved during prolonged exercise if desired, but aggressive insulin dose adjustments are likely to be needed [51] (B), [74] (B), [75] (D).

Post-exercise period During the first 90 min following exercise, an interstitial glycaemic range of $4.4 \mathrm{mmol} / 1$ to $10.0 \mathrm{mmol} / 1$ $(80 \mathrm{mg} / \mathrm{dl}$ to $180 \mathrm{mg} / \mathrm{dl})$ might be targeted in the majority of people with type 1 diabetes who are at a low risk of hypoglycaemia, reflecting the clinical targets for CGM and isCGM [41] (D) with a slightly increased lower glycaemic limit, as recently recommended [76] (D). People with an elevated risk of hypoglycaemia are recommended to increase the lower limit of sensor glucose to $5.0 \mathrm{mmol} / 1(90 \mathrm{mg} / \mathrm{dl})$ or $5.6 \mathrm{mmol} / \mathrm{l}$ (100 mg/dl) during the post-exercise period [58] (D). Sensor glucose may be monitored regularly via CGM, or every 15$30 \mathrm{~min}$ in the case of isCGM, during the $90 \mathrm{~min}$ post-exercise period, and the hypoglycaemia alert can be set at $4.4 \mathrm{mmol} / \mathrm{l}$ $(80 \mathrm{mg} / \mathrm{dl}), 5.0 \mathrm{mmol} / \mathrm{l}(90 \mathrm{mg} / \mathrm{dl})$ or $5.6 \mathrm{mmol} / \mathrm{l}(100 \mathrm{mg} / \mathrm{dl})$ based on the risk of hypoglycaemia. If sensor glucose is rapidly increasing in the post-exercise phase (detected by CGM when using the rate-of-change alert), then an insulin correction can be considered (50\% of typical correction dose) [68] (D), [69] (D). If exercise was performed at a moderate-to-high intensity and/or for a long duration, then glucose may decrease during the acute post-exercise period, as seen in experimental studies [74, 77]. At a glycaemic threshold of $4.4 \mathrm{mmol} / 1(80 \mathrm{mg} / \mathrm{dl})$ or slightly higher, based on the risk of hypoglycaemia [76], accompanied by a horizontal trend arrow, $\sim 10 \mathrm{~g}$ of carbohydrates are recommended to be consumed; $15 \mathrm{~g}$ of carbohydrates should be consumed if accompanied by a (slight) downward trend arrow; an individual amount of carbohydrates should be consumed if accompanied by rapidly falling downward trend arrows (Table 3) [38] (D), [39] (D), [40] (D), [44] (D), [45] (D). Treatment should be repeated if sensor glucose is not rising within $30 \mathrm{~min}$ as reflected by trend arrows. If an interstitial level $<3.0 \mathrm{mmol} / \mathrm{l}(<54 \mathrm{mg} / \mathrm{dl})$ is displayed, rapidly acting carbohydrates should be given and a confirmatory SMBG may be 
Table 5 Sensor glucose targets in advance to exercise in regard to different groups of children and adolescents with type 1 diabetes

\begin{tabular}{|c|c|c|c|c|c|}
\hline \multicolumn{3}{|c|}{$\begin{array}{l}\text { Pre-exercise sensor glucose for } \\
\text { different groups in T1D }\end{array}$} & \multirow{2}{*}{$\begin{array}{l}\text { Trend } \\
\text { arrow } \\
\text { Direction }\end{array}$} & \multicolumn{2}{|c|}{ Action } \\
\hline $\begin{array}{c}\text { Ex } 2 \\
\text { and/or } \\
\text { low } \\
\text { hypo risk }\end{array}$ & $\begin{array}{c}\text { Ex } 1 \\
\text { and/or } \\
\text { moderate } \\
\text { hypo risk }\end{array}$ & $\begin{array}{c}\text { Ex 0 } \\
\text { and/or } \\
\text { high } \\
\text { hypo risk }\end{array}$ & & $\begin{array}{l}\text { Increase in sensor } \\
\text { glucose expected }\end{array}$ & $\begin{array}{l}\text { Decrease in sensor } \\
\text { glucose expected }\end{array}$ \\
\hline \multicolumn{3}{|c|}{$\begin{array}{c}>15.0 \mathrm{mmol} / \mathrm{l}(>270 \mathrm{mg} / \mathrm{dl}) \\
\text { AND }>1.5 \mathrm{mmol} / / \text { blood ketones }\end{array}$} & ヘス $\rightarrow$ & \multicolumn{2}{|c|}{$\begin{array}{c}\text { No Ex, } \\
\text { Insulin correction }\end{array}$} \\
\hline \multirow{3}{*}{\multicolumn{3}{|c|}{$\begin{array}{c}>15.0 \mathrm{mmol} / \mathrm{l}(>270 \mathrm{mg} / \mathrm{dl}) \\
\text { AND } \leq 1.5 \mathrm{mmol} / \mathrm{l} \text { blood ketones }\end{array}$}} & スト & $\begin{array}{l}\text { Consider insulin } \\
\text { correction }{ }^{\mathrm{a}}, \\
\text { Can start AE }\end{array}$ & $\begin{array}{l}\text { Consider insulin } \\
\text { correction } \\
\text { Can start all Ex }\end{array}$ \\
\hline & & & $\rightarrow$ & $\begin{array}{l}\text { Consider insulin } \\
\text { correction }{ }^{\mathrm{a}}, \\
\text { Can start AE }\end{array}$ & Can start all Ex \\
\hline & & & $\boldsymbol{y} \downarrow$ & \multicolumn{2}{|c|}{ Can start all Ex } \\
\hline \multirow{2}{*}{$\begin{array}{c}10.1-15.0 \\
\mathrm{mmol} / \mathrm{l} \\
(181-270 \\
\mathrm{mg} / \mathrm{dl})\end{array}$} & \multirow{2}{*}{$\begin{array}{c}11.1-15.0 \\
\mathrm{mmol} / \mathrm{l} \\
(199-270 \\
\mathrm{mg} / \mathrm{dl})\end{array}$} & \multirow{2}{*}{$\begin{array}{c}12.1-15.0 \\
\mathrm{mmol} / \mathrm{l} \\
(217-270 \\
\mathrm{mg} / \mathrm{dl})\end{array}$} & スト & Can start AE & Can start all Ex \\
\hline & & & $\begin{array}{l}\rightarrow \\
y \downarrow\end{array}$ & \multicolumn{2}{|c|}{ Can start all Ex } \\
\hline \multirow{3}{*}{$\begin{array}{c}7.0-10.0 \\
\mathrm{mmol} / \mathrm{l} \\
(126-180 \\
\mathrm{mg} / \mathrm{dl})\end{array}$} & \multirow{3}{*}{$\begin{array}{c}8.0-11.0 \\
\mathrm{mmol} / \mathrm{l} \\
(145-198 \\
\mathrm{mg} / \mathrm{dl})\end{array}$} & \multirow{3}{*}{$\begin{array}{c}9.0-12.0 \\
\mathrm{mmol} / \mathrm{l} \\
(162-216 \\
\mathrm{mg} / \mathrm{dl})\end{array}$} & 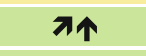 & \multirow{2}{*}{\multicolumn{2}{|c|}{ Can start all Ex }} \\
\hline & & & $\rightarrow$ & & \\
\hline & & & $\boldsymbol{y} \downarrow$ & $\begin{array}{c}\sim 5 \mathrm{~g} \mathrm{CHO} \\
(0.2 \mathrm{~g} / \mathrm{kg}) \\
\text { Can start all Ex }\end{array}$ & $\begin{array}{c}\sim 10 \mathrm{~g} \mathrm{CHO} \\
(0.3 \mathrm{~g} / \mathrm{kg}), \\
\text { Can start all Ex }\end{array}$ \\
\hline \multirow{4}{*}{$\begin{array}{c}5.0-6.9 \\
\mathrm{mmol} / \mathrm{l} \\
(90-125 \\
\mathrm{mg} / \mathrm{dl})\end{array}$} & \multirow{4}{*}{$\begin{array}{c}5.0-7.9 \\
\mathrm{mmol} / \mathrm{l} \\
(90-144 \\
\mathrm{mg} / \mathrm{dl})\end{array}$} & \multirow{4}{*}{$\begin{array}{c}5.0-8.9 \\
\mathrm{mmol} / \mathrm{l} \\
(90-161 \\
\mathrm{mg} / \mathrm{dl}\end{array}$} & スト & Can start all Ex & $\begin{array}{c}\sim 5 \mathrm{~g} \mathrm{CHO} \\
(0.2 \mathrm{~g} / \mathrm{kg}), \\
\text { Can start all Ex }\end{array}$ \\
\hline & & & $\rightarrow$ & $\begin{array}{c}\sim 5 \mathrm{~g} \mathrm{CHO} \\
(0.2 \mathrm{~g} / \mathrm{kg}), \\
\text { Can start all Ex }\end{array}$ & $\begin{array}{c}\sim 10 \mathrm{~g} \mathrm{CHO} \\
(0.3 \mathrm{~g} / \mathrm{kg}), \\
\text { Can start all Ex }\end{array}$ \\
\hline & & & $y$ & $\begin{array}{l}\sim 10 \mathrm{~g} \mathrm{CHO} \\
(0.3 \mathrm{~g} / \mathrm{kg}), \\
\text { Delay all } \mathrm{Ex}^{\mathrm{b}}\end{array}$ & $\begin{array}{l}\sim 15 \mathrm{~g} \mathrm{CHO} \\
(0.4 \mathrm{~g} / \mathrm{kg}) \\
\text { Delay all } \mathrm{Ex}^{\mathrm{b}}\end{array}$ \\
\hline & & & $\downarrow$ & \multicolumn{2}{|c|}{$\begin{array}{c}\text { Individual amount } \mathrm{CHO} \text { ingestion, } \\
\text { Delay all } \mathrm{Ex}^{\mathrm{b}}\end{array}$} \\
\hline & \multicolumn{2}{|l|}{$\begin{array}{l}<5.0 \mathrm{mmol} / \mathrm{l} \\
(<90 \mathrm{mg} / \mathrm{dl})\end{array}$} & & \multicolumn{2}{|c|}{$\begin{array}{l}\text { Individual amount } \mathrm{CHO} \text { ingestion, } \\
\text { Delay all } \mathrm{Ex}^{\mathrm{b}}\end{array}$} \\
\hline
\end{tabular}

Sensor glucose targets are detailed for the following groups in type 1 diabetes (T1D): intensively exercising and/or low risk of hypoglycaemia (Ex 2); moderately exercising and/or moderate risk of hypoglycaemia (Ex 1), minimally exercising and/or high risk of hypoglycaemia (Ex 0)

${ }^{a} 50 \%$ of regular insulin correction factor when sensor glucose is close to the upper glycaemic threshold

${ }^{\mathrm{b}}$ Delay exercise until reaching at least $5.0 \mathrm{mmol} / \mathrm{l}(90 \mathrm{mg} / \mathrm{dl})$ and, ideally, from $7.0 \mathrm{mmol} / \mathrm{l}$ to $10.0 \mathrm{mmol} / \mathrm{l}(126 \mathrm{mg} / \mathrm{dl}$ to $180 \mathrm{mg} / \mathrm{dl}) \mathrm{or}$ higher in those with an increased risk of hypoglycaemia accompanied by $\rightarrow, \boldsymbol{\gamma}$, or $\boldsymbol{\uparrow}$

When reaching the required sensor glucose level to start exercise, only consume carbohydrates again when the trend arrow is starting to decrease These recommendations are not applicable to hybrid closed-loop systems

Green shading, no/minimal action required; light-yellow shading, minimal/moderate action required; dark-yellow shading, moderate/intense action required; red shading, no/delay exercise

$\mathrm{AE}$, mild-to-moderate intensity aerobic exercise; $\mathrm{CHO}$, carbohydrates; Ex, exercise; hypo, hypoglycaemia

performed. Exogenous glucagon is recommended if the person is unable to self-treat [78] (B).

Nocturnal post-exercise period Following an evening or late afternoon exercise session, or an exercise session of high intensity and long duration, people with type 1 diabetes are at an elevated risk of nocturnal hypoglycaemia, as shown in experimental and observational studies [79, 80]. Hypoglycaemia typically occurs within 6 to $15 \mathrm{~h}$ after exercise, although the risk may remain longer, as seen in children and adolescents, as well as in adults $[81,82]$. People using a CGM system should, therefore, set the hypoglycaemia alert at $4.4 \mathrm{mmol} / 1(80 \mathrm{mg} / \mathrm{dl})$ during the night-time period, or higher for groups with an elevated risk of hypoglycaemia to allow for earlier proactive treatments [76] (D). When reaching glucose levels of $4.4 \mathrm{mmol} / \mathrm{l}(80 \mathrm{mg} / \mathrm{dl})$, or higher if deemed necessary, the following carbohydrate guidance can be applied [38] (D), [39] (D), [40] (D), [44] (D), [45] (D): with a horizontal trend arrow, $\sim 10 \mathrm{~g}$ of carbohydrates are recommended to be consumed; $15 \mathrm{~g}$ of carbohydrates should be consumed if 
Table 6 Sensor glucose targets during exercise in regard to different groups of children and adolescents with type 1 diabetes

\begin{tabular}{|c|c|c|c|c|c|}
\hline \multicolumn{3}{|c|}{$\begin{array}{l}\text { During exercise sensor glucose for different } \\
\text { groups in T1D }\end{array}$} & \multirow{2}{*}{$\begin{array}{l}\begin{array}{l}\text { Trend } \\
\text { arrow }\end{array} \\
\text { Direction }\end{array}$} & \multicolumn{2}{|c|}{ Action } \\
\hline $\begin{array}{l}\text { Ex } 2 \text { and/or low } \\
\text { hypo risk }\end{array}$ & $\begin{array}{c}\text { Ex } 1 \\
\text { and/or } \\
\text { moderate } \\
\text { hypo risk }\end{array}$ & $\begin{array}{c}\text { Ex } 0 \\
\text { and/or } \\
\text { high } \\
\text { hypo risk }\end{array}$ & & $\begin{array}{l}\text { Increase in sensor } \\
\text { glucose expected }\end{array}$ & $\begin{array}{l}\text { Decrease in sensor } \\
\text { glucose expected }\end{array}$ \\
\hline \multicolumn{3}{|c|}{$\begin{array}{l}>15.0 \mathrm{mmol} / \mathrm{l}(>270 \mathrm{mg} / \mathrm{dl}) \\
\text { AND }>1.5 \mathrm{mmol} / \mathrm{l} \text { blood ketones }\end{array}$} & 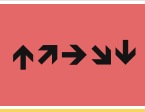 & \multicolumn{2}{|c|}{$\begin{array}{c}\text { Stop Ex, } \\
\text { Consider insulin correction, } \\
\text { No restart of Ex }\end{array}$} \\
\hline \multirow{3}{*}{\multicolumn{3}{|c|}{$\begin{array}{l}>15.0 \mathrm{mmol} / \mathrm{l}(>270 \mathrm{mg} / \mathrm{dl}) \\
\text { AND } \leq 1.5 \mathrm{mmol} / / \text { blood ketones }\end{array}$}} & スト & $\begin{array}{l}\text { Consider insulin } \\
\text { correction }{ }^{\mathrm{b}} \\
\text { Proceed all Ex }\end{array}$ & $\begin{array}{l}\text { Proceed all Ex, } \\
\text { Consider } \mathrm{AE}\end{array}$ \\
\hline & & & $\rightarrow$ & $\begin{array}{l}\text { Consider insulin } \\
\text { correction }^{\mathrm{b}} \text {, } \\
\text { Proceed all Ex }\end{array}$ & Proceed all Ex \\
\hline & & & עע & \multicolumn{2}{|c|}{ Proceed all Ex } \\
\hline \multirow{3}{*}{$\begin{array}{c}10.1-15.0 \\
\mathrm{mmol} / \mathrm{l} \\
(181-270 \\
\mathrm{mg} / \mathrm{dl})\end{array}$} & \multirow{3}{*}{$\begin{array}{c}11.1-15.0 \\
\mathrm{mmol} / \mathrm{l} \\
(199-270 \\
\mathrm{mg} / \mathrm{dl})\end{array}$} & \multirow{3}{*}{$\begin{array}{c}12.1-15.0 \\
\mathrm{mmol} / \mathrm{l} \\
(217-270 \\
\mathrm{mg} / \mathrm{dl})\end{array}$} & スト & \multirow{2}{*}{$\begin{array}{l}\text { Proceed all Ex, } \\
\text { Consider insulin } \\
\text { correction }^{\mathrm{b}}\end{array}$} & \multirow[b]{2}{*}{ Proceed all Ex } \\
\hline & & & $\rightarrow$ & & \\
\hline & & & עע & \multicolumn{2}{|c|}{ Proceed all Ex } \\
\hline \multirow{3}{*}{$\begin{array}{c}7.0-10.0 \\
\mathrm{mmol} / \mathrm{l} \\
(126-180 \\
\mathrm{mg} / \mathrm{dl})\end{array}$} & \multirow{3}{*}{$\begin{array}{c}8.0-11.0 \\
\mathrm{mmol} / \mathrm{l} \\
(145-198 \\
\mathrm{mg} / \mathrm{dl})\end{array}$} & \multirow{3}{*}{$\begin{array}{c}9.0-12.0 \\
\mathrm{mmol} / \mathrm{l} \\
(162-216 \\
\mathrm{mg} / \mathrm{dl})\end{array}$} & ス个 & \multirow{3}{*}{\multicolumn{2}{|c|}{ Proceed all Ex }} \\
\hline & & & $\Rightarrow$ & & \\
\hline & & & $\boldsymbol{y} \downarrow$ & & \\
\hline \multirow{4}{*}{$\begin{array}{c}<7.0 \\
\mathrm{mmol} / \mathrm{l} \\
(<126 \\
\mathrm{mg} / \mathrm{dl})\end{array}$} & \multirow{4}{*}{$\begin{array}{c}<8.0 \\
\mathrm{mmol} / \mathrm{l} \\
(<145 \\
\mathrm{mg} / \mathrm{dl})\end{array}$} & \multirow{4}{*}{$\begin{array}{c}<9.0 \\
\mathrm{mmol} / \mathrm{l} \\
(<162 \\
\mathrm{mg} / \mathrm{dl})\end{array}$} & スト & \multicolumn{2}{|c|}{ Proceed all Ex } \\
\hline & & & $\rightarrow$ & $\begin{array}{c}\sim 5 \mathrm{~g} \mathrm{CHO} \\
(\sim 0.2 \mathrm{~g} / \mathrm{kg}), \\
\text { Proceed all } \mathrm{Ex}^{\mathrm{c}}\end{array}$ & $\begin{array}{c}\sim 10 \mathrm{~g} \mathrm{CHO} \\
(\sim 0.3 \mathrm{~g} / \mathrm{kg}), \\
\text { Proceed all Ex }\end{array}$ \\
\hline & & & $y$ & $\begin{array}{c}\sim 10 \mathrm{~g} \mathrm{CHO} \\
(\sim 0.3 \mathrm{~g} / \mathrm{kg}) \\
\text { Proceed all Ex }\end{array}$ & $\begin{array}{c}\sim 15 \mathrm{~g} \mathrm{CHO} \\
(\sim 0.4 \mathrm{~g} / \mathrm{kg}), \\
\text { Proceed all Ex }\end{array}$ \\
\hline & & & $\downarrow$ & $\begin{array}{c}\sim 15 \mathrm{~g} \mathrm{CHO} \\
(\sim 0.4 \mathrm{~g} / \mathrm{kg}), \\
\text { Proceed all Ex }\end{array}$ & $\begin{array}{c}\sim 20 \mathrm{~g} \mathrm{CHO} \\
(\sim 0.4-0.5 \mathrm{~g} / \mathrm{kg}), \\
\text { Proceed all Ex }\end{array}$ \\
\hline \multirow{5}{*}{\multicolumn{3}{|c|}{$\begin{array}{l}<5.0 \mathrm{mmol} / \mathrm{l} \\
(<90 \mathrm{mg} / \mathrm{dl})\end{array}$}} & $\uparrow$ & \multirow{5}{*}{\multicolumn{2}{|c|}{$\begin{array}{c}\text { Stop all Ex, } \\
\text { Consider confirmatory SMBG, } \\
\text { Individual amount CHO ingestion, } \\
\text { Restart of all Ex possible }{ }^{d}\end{array}$}} \\
\hline & & & $\pi$ & & \\
\hline & & & $\rightarrow$ & & \\
\hline & & & $y$ & & \\
\hline & & & $\downarrow$ & & \\
\hline \multicolumn{3}{|c|}{$\begin{array}{l}<3.0 \mathrm{mmol} / \mathrm{l} \\
(<54 \mathrm{mg} / \mathrm{dl})\end{array}$} & \multicolumn{3}{|c|}{$\begin{array}{c}\text { Stop all Ex, } \\
\text { Confirmatory SMBG, } \\
\text { Individual amount } \mathrm{CHO} \text { ingestion, } \\
\text { No restart of Ex }\end{array}$} \\
\hline
\end{tabular}

Sensor glucose targets are detailed for the following groups in type 1 diabetes (T1D): intensively exercising and/or low risk of hypoglycaemia (Ex 2); moderately exercising and/or moderate risk of hypoglycaemia (Ex 1); minimally exercising and/or high risk of hypoglycaemia (Ex 0 )

${ }^{a}$ Elevated blood ketone levels should lead to repeated controls after exercise to ensure that ketosis (blood ketones $>1.5$ mmol/l) or diabetic ketoacidosis is not developed. If sensor glucose is $>15.0 \mathrm{mmol} / 1$ ( $>270 \mathrm{mg} / \mathrm{dl})$ and blood ketones are $\leq 1.5 \mathrm{mmol} / \mathrm{l}$, then only mild aerobic exercise may be performed ${ }^{\mathrm{b}} 50 \%$ of regular insulin correction factor when sensor glucose is close to the upper glycaemic threshold

${ }^{\mathrm{c}}$ Check sensor glucose at least $30 \mathrm{~min}$ after carbohydrate consumption and repeat treatment if required

${ }^{\mathrm{d}}$ Restart exercise when reaching at least sensor glucose levels of $5.0 \mathrm{mmol} / \mathrm{l}(90 \mathrm{mg} / \mathrm{dl})$ and $\boldsymbol{7}$ or $\boldsymbol{\uparrow}$

When reaching the required sensor glucose level during exercise, only consume carbohydrates again when the trend arrow is starting to decrease

These recommendations are not applicable to hybrid closed-loop systems

Green shading, no/minimal action required; light-yellow shading, minimal/moderate action required; dark-yellow shading, moderate/intense action required; red shading, stop exercise

$\mathrm{AE}$, mild-to-moderate intensity aerobic exercise; $\mathrm{CHO}$, carbohydrates; Ex, exercise; hypo, hypoglycaemia 
Table 7 Sensor glucose targets for carbohydrates consumption during the post-exercise phase, including the nocturnal post-exercise phase if exercise was performed in the late afternoon/evening, in children and adolescents with type 1 diabetes

\begin{tabular}{|c|c|c|c|c|}
\hline \multicolumn{3}{|c|}{$\begin{array}{l}\text { Post-exercise sensor glucose, including nocturnal phase, } \\
\text { for different groups in T1D }\end{array}$} & \multirow{2}{*}{$\begin{array}{l}\begin{array}{c}\text { Trend } \\
\text { arrow }\end{array} \\
\text { Direction }\end{array}$} & \multirow{2}{*}{$\begin{array}{l}\text { Action } \\
\mathrm{CHO}(\mathrm{g})\end{array}$} \\
\hline $\begin{array}{l}\text { Ex } 2 \text { and/or } \\
\text { low hypo risk }\end{array}$ & $\begin{array}{l}\text { Ex } 1 \text { and/or } \\
\text { moderate hypo risk }\end{array}$ & $\begin{array}{l}\text { Ex } 0 \text { and/or } \\
\text { high hypo risk }\end{array}$ & & \\
\hline \multirow{4}{*}{$\begin{array}{l}<4.4 \mathrm{mmol} / \mathrm{l} \\
(<80 \mathrm{mg} / \mathrm{dl})\end{array}$} & \multirow{4}{*}{$\begin{array}{l}<5.0 \mathrm{mmol} / \mathrm{l} \\
(<90 \mathrm{mg} / \mathrm{dl})\end{array}$} & \multirow{4}{*}{$\begin{array}{l}<5.6 \mathrm{mmol} / \mathrm{l} \\
(<100 \mathrm{mg} / \mathrm{dl})\end{array}$} & $\begin{array}{l}\uparrow \\
\boldsymbol{\lambda}\end{array}$ & $\mathrm{No} \mathrm{CHO}$ \\
\hline & & & $\rightarrow$ & $\begin{array}{l}\sim 5 \mathrm{~g} \mathrm{CHO} \\
(\sim 0.2 \mathrm{~g} / \mathrm{kg})\end{array}$ \\
\hline & & & y & $\begin{array}{l}\sim 10 \mathrm{~g} \mathrm{CHO} \\
(\sim 0.3 \mathrm{~g} / \mathrm{kg})\end{array}$ \\
\hline & & & $\downarrow$ & $\begin{array}{l}\text { Individual amount } \\
\mathrm{CHO} \text { ingestion }\end{array}$ \\
\hline
\end{tabular}

Sensor glucose threshold for treatments is detailed for the following groups with type 1 diabetes (T1D): intensively exercising and/or low risk of hypoglycaemia (Ex 2); moderately exercising and/or moderate risk of hypoglycaemia (Ex 1); minimally exercising and/or high risk of hypoglycaemia (Ex 0)

If an insulin correction is applied due to high sensor glucose levels, then the regular correction factor might be reduced by up to $50 \%$

These recommendations are not applicable to hybrid closed-loop systems

The intensity of yellow shading indicates the level of action required: lighter yellow shading indicates that minimal/moderate action is required, while darker yellow shading indicates that moderate/intense action is required

CHO, carbohydrates; Ex, exercise; hypo, hypoglycaemia

accompanied by a (slight) downward trend arrow; and an individual amount of carbohydrates should be consumed if accompanied by downward trend arrows. These recommendations might also be applied for the second generation of isCGM systems where a real-time alert is given when reaching hypoand hyperglycaemia threshold.

People using an isCGM system should perform at least one scan during the night-time period, preferably between midnight and 03:00 hours, since this is typically the nocturnal nadir after exercise [83] (D). Carbohydrates should be given at a sensor glucose level of $4.4 \mathrm{mmol} / \mathrm{l}(80 \mathrm{mg} / \mathrm{dl})$ or earlier in people with an elevated risk of hypoglycaemia, following the same strategy as given for CGM [76] (D) (Table 3). When carbohydrates were consumed after reaching this lower threshold, a scan should be performed no later than $2 \mathrm{~h}$ afterwards. If considered necessary, this procedure should be repeated frequently based on the lower glycaemic threshold and trend arrow.

\section{Children and adolescents with type 1 diabetes}

Exercise may improve glycaemic control, blood lipid profiles, physical fitness and quality of life and can decrease the total daily dose of insulin in children and adolescents with type 1 diabetes, as shown in randomised controlled trials and in a systematic review [84-87]. Despite the positive effects of exercise, deterioration of diabetes control, fear of hypoglycaemia and other exercise-related fears similar to the ones experienced by children without diabetes are major barriers to an active lifestyle in children and adolescents with type 1 diabetes, as assessed via questionnaire [88]. Furthermore, parents of children and adolescents with type 1 diabetes reported a conflict between the need for planned activity to control glucose levels and the spontaneous nature of children's usual activity [89]. Therefore, children and adolescents, as well as their parents, should actively participate in consultations with the healthcare professional team, as parental support appears to be the key to an active lifestyle [88] (C).

Hypo- and hyperglycaemic alerts should be set at $5.6 \mathrm{mmol} / \mathrm{l}$ $(100 \mathrm{mg} / \mathrm{dl})$ and $10.0 \mathrm{mmol} / \mathrm{l}(180 \mathrm{mg} / \mathrm{dl})$ or individualised if required [40] (D), [44] (D), [45] (D). The rate-of-glucose-change alerts should be used to initiate an earlier action [40] (D), [44] (D), [45] (D). The use of remote monitors (e.g., via a mobile phone application to remotely follow sensor glucose in realtime) should be used to assess and react to glycaemic excursions during exercise [40] (D). Both parents and most caregivers report a decreased overall worry and stress when using remote monitoring [90, 91]. Carbohydrate supplementation might be performed in relation to the individual body weight or as an absolute amount [40] (D); however, it was shown that weightadjusted carbohydrate supplementation is more effective to treat hypoglycaemia in children with type 1 diabetes in a randomised crossover study [92]. The guidelines in Table 4 can be followed for exercise, which are in alignment with the ISPAD Clinical Practice Consensus Guidelines 2018: exercise in children and adolescents with diabetes, and other consensus and position statements [38] (D), [39] (D), [40] (D).

Preparation in advance to exercise For the immediate preexercise phase, the target sensor glucose range should be between $7.0 \mathrm{mmol} / \mathrm{l}$ and $10.0 \mathrm{mmol} / \mathrm{l}(126 \mathrm{mg} / \mathrm{dl}$ and $180 \mathrm{mg} /$ $\mathrm{dl}$ ), or between $8.0 \mathrm{mmol} / \mathrm{l}$ and $11.0 \mathrm{mmol} / \mathrm{l}(145 \mathrm{mg} / \mathrm{dl}$ and $198 \mathrm{mg} / \mathrm{dl}$ ) for children and adolescents moderately exercising 
and/or with a moderate risk of hypoglycaemia, and $9.0 \mathrm{mmol} / \mathrm{l}$ and $12.0 \mathrm{mmol} / \mathrm{l}(162 \mathrm{mg} / \mathrm{dl}$ and $216 \mathrm{mg} / \mathrm{dl})$ for children and adolescents minimally exercising and/or with a high risk of hypoglycaemia [40] (D), [93] (D). These glucose targets can be achieved by mealtime insulin dose reduction ranging from 25\% to 75\% (Table 4) [38] (D), [39] (D), [40] (D). Bolus insulin dose reduction can be based on the individual glucose response to the type, intensity and duration of exercise [94] (D). If sensor glucose concentration is below these glycaemic targets, then small amounts of oral carbohydrates should be consumed (e.g. 10-15 g of carbohydrates) [40] (D), [44] (D), [45] (D). Exercise may be started when reaching $5.0 \mathrm{mmol} / \mathrm{l}(90 \mathrm{mg} / \mathrm{dl})$ glucose and, ideally, from $7.0 \mathrm{mmol} / 1$ to $10.0 \mathrm{mmol} / 1$ (126 mg/dl to $180 \mathrm{mg} / \mathrm{dl}$ ) or higher in those with an increased risk of hypoglycaemia (Table 5) [40] (D). Depending on the trend arrows on the CGM or isCGM, $5 \mathrm{~g}, 10 \mathrm{~g}, 15 \mathrm{~g}$ or more carbohydrates may be consumed when reaching the predefined lower glycaemic thresholds [40] (D), [44] (D), [45] (D). At an upper limit of $>15.0 \mathrm{mmol} / \mathrm{l}(>270 \mathrm{mg} / \mathrm{dl})$ and blood ketone levels $>1.5 \mathrm{mmol} / \mathrm{l}$, exercise is contraindicated and blood ketone levels of 0.6-1.4 mmol/1 should be addressed before exercise [40] (D), [95] (D), [96] (D). In the case of extreme hyperglycaemia, an insulin correction might be applied (50\% of a typical correction dose) [97] (D). When using a CGM or a second-generation isCGM, the hypoglycaemia alert threshold should be set at $5.6 \mathrm{mmol} / \mathrm{l}(100 \mathrm{mg} / \mathrm{dl})$ and the hyperglycaemia alert threshold should be set at $10.0 \mathrm{mmol} / \mathrm{l}(180 \mathrm{mg} / \mathrm{dl})$ or higher in those with an elevated risk of hypoglycaemia [40] (D), [44] (D), [45] (D). Predictive hypoglycaemia thresholds, as well as rate-of-changein-glucose alerts, should be switched on for CGM [40] (D), [44] (D), [45] (D). Remote devices can be used by parents and caregivers to facilitate supportive action during exercise in children and adolescents with type 1 diabetes [90] (D). The strategies given in Table 5 should be applied to achieve the recommended glycaemic targets [40] (D), [44] (D), [45] (D).

During exercise Sensor glucose ranges of $5.0 \mathrm{mmol} / \mathrm{l}$ to $10.0 \mathrm{mmol} / 1(90 \mathrm{mg} / \mathrm{dl}$ to $180 \mathrm{mg} / \mathrm{dl})$ and, ideally, of $7.0 \mathrm{mmol} / \mathrm{l}$ to $10.0 \mathrm{mmol} / \mathrm{l}(126 \mathrm{mg} / \mathrm{dl}$ to $180 \mathrm{mg} / \mathrm{dl})$ should be targeted for exercise [40] (D), [44] (D), [45] (D). These ranges should be higher for children and adolescents who are minimally exercising and/or with a higher risk of hypoglycaemia (Table 6) [40] (D), [44] (D), [45] (D). Carbohydrate consumption at a lower threshold of $7.0 \mathrm{mmol} / 1(126 \mathrm{mg} / \mathrm{dl}), 8.0 \mathrm{mmol} / 1$ $(145 \mathrm{mg} / \mathrm{dl})$ or $9.0 \mathrm{mmol} / \mathrm{l}(162 \mathrm{mg} / \mathrm{dl})$, based on the risk of hypoglycaemia, with respect to trend arrows has been shown to avoid significant hypoglycaemia in children with type 1 diabetes [40] (D), [44] (D), [45] (D). If sensor glucose is $>15.0 \mathrm{mmol} / 1$ (>270 mg/dl), blood ketones should be measured [40] (D), [95] (D), [96] (D). If blood ketones are $>1.5 \mathrm{mmol} / 1$, exercise should be stopped, the source of hyperglycaemia should be assessed and an insulin correction might be applied (50\% of typical correction dose) [97] (D). Elevated blood ketone levels should lead to repeated glucose and blood ketone measurements after exercise to ensure that ketosis (blood ketones $>1.5 \mathrm{mmol} / \mathrm{l}$ ) or diabetic ketoacidosis is not developed. If sensor glucose is $>15.0 \mathrm{mmol} / \mathrm{l}(>270 \mathrm{mg} / \mathrm{dl})$ and blood ketones are $\leq 1.5 \mathrm{mmol} /$ 1 , then only mild aerobic exercise may be performed to avoid a further increase in glucose levels by sympathoadrenal responses to intense (an)aerobic exercise [98] (D). Exercise may be stopped at a sensor glucose level of $<5.0 \mathrm{mmol} / \mathrm{l}(<90 \mathrm{mg} / \mathrm{dl})$, SMBG may be performed and carbohydrates should be consumed [40] (D), [95] (D), [96] (D). Exercise may be restarted when reaching a sensor glucose level of $5.0 \mathrm{mmol} / \mathrm{l}(90 \mathrm{mg} / \mathrm{dl})$ accompanied by horizontal or upward trend arrows. Exercise should not be commenced when reaching a sensor glucose level of $<3.0 \mathrm{mmol} / \mathrm{l}(<54 \mathrm{mg} / \mathrm{dl})$. Sensor glucose may be checked every $15 \mathrm{~min}$ during exercise and parents/caregivers are recommended to observe sensor glucose levels via a remote device [99] (D). With respect to the specific trend arrow, a certain amount of carbohydrates may be consumed at a lower glycaemic threshold of $7.0 \mathrm{mmol} / \mathrm{l}(126 \mathrm{mg} / \mathrm{dl}$ ) or higher (Table 6), which should be further personalised in line with individual characteristics [40] (D), [44] (D), [45] (D).

Post-exercise period Up to $2 \mathrm{~h}$ after exercise, children and adolescents may refill the intramuscular and hepatic glycogen storages via carbohydrates and protein, similar to recommendations for children and adolescents without diabetes [100]. After finishing exercise, the sensor glucose target should be between $4.4 \mathrm{mmol} / \mathrm{l}$ and $10.0 \mathrm{mmol} / \mathrm{l}(80 \mathrm{mg} / \mathrm{dl}$ and $180 \mathrm{mg} / \mathrm{dl})$ or higher, based on the risk of hypoglycaemia, in the $90 \mathrm{~min}$ post-exercise period [40] (D), [76] (D) (Table 7). If sensor glucose levels increase rapidly post exercise, then an insulin correction can be considered ( $50 \%$ of typical correction dose), based on the individual's insulin sensitivity factor and sensor glucose level [97] (D). However, correctional insulin dose close to bedtime should be avoided since it may increase the risk of post-exercise nocturnal hypoglycaemia. Importantly, frequently checking sensor glucose values should be stressed to help to reduce the likelihood of developing post-exercise late-onset hypoglycaemia following bolus insulin correction.

If the sensor glucose level falls below $4.4 \mathrm{mmol} / \mathrm{l}$ (below $80 \mathrm{mg} / \mathrm{dl}$ ) for children and adolescents of typical hypoglycaemia risk, then oral carbohydrates should be given; carbohydrates should be given at a higher glycaemic threshold for individuals at higher risk of hypoglycaemia (Table 7) [38] (D), [39] (D), [40] (D). Oral carbohydrate consumption should be repeated, as required, to stabilise glucose levels. There will be a time delay of up to $20 \mathrm{~min}$ following oral carbohydrate consumption before a change in the trend arrow should be expected to be observed.

Nocturnal post-exercise period Children and adolescents may set the hypoglycaemia alert threshold at $4.4 \mathrm{mmol} / \mathrm{l}(80 \mathrm{mg} / \mathrm{dl})$, or even higher in those with a higher risk of hypoglycaemia, to be able to prospectively counteract impending hypoglycaemia 
[76] (D). When reaching this lower threshold, the guidance as shown in Table 7 can be followed and further individualised, if required. Children and adolescents using an isCGM should perform a scan at least twice during the nocturnal period (e.g. at 01:00 hours and 04:00 hours) due to the increased risk of nocturnal hypoglycaemia [101-104] (D), especially after exercise [81, 104-106] (D). Parents or other care providers can be alerted using the remote monitoring function within CGMs, which can support parents in their effort to avoid nocturnal hypoglycaemia in children [91] (D). In addition to the intake of carbohydrates, the insulin strategies mentioned in Table 4 should also be applied to lower the risk of nocturnal hypoglycaemia [38] (D), [39] (D), [40] (D).

\section{Points to consider when using CGM/isCGM around exercise}

\section{Before exercise}

- Know type, intensity and duration of exercise

- Consider timing of exercise

- Know how much insulin on board

- Target a sensor glucose range based on exercise routine and risk of hypoglycaemia accompanied by adequate trend arrow

\section{During exercise}

- Target sensor glucose ranges should be between $7.0 \mathrm{mmol} / \mathrm{l}$ and $10.0 \mathrm{mmol} / \mathrm{l}(126 \mathrm{mg} / \mathrm{dl}$ and $180 \mathrm{mg} / \mathrm{dl})$ and slightly higher for those with an increased risk of hypoglycaemia

- At a glycaemic threshold of $7.0 \mathrm{mmol} / \mathrm{l}(126 \mathrm{mg} / \mathrm{dl})$, accompanied by a horizontal trend arrow, 10-15 g of carbohydrates should be consumed; $15-25 \mathrm{~g}$ carbohydrates should be consumed immediately if accompanied by a (slightly) downward trend arrow; 20-35 g of carbohydrates should be consumed if accompanied with a downward trending arrow

- If sensor glucose levels are elevated (>15.0 mmol/l [>270 mg/dl]), monitor blood ketone levels, and an insulin correction may be performed ( $50 \%$ of individual's regular correction factor)

- Exercise should be suspended in adults if the sensor glucose level reaches $<3.9 \mathrm{mmol} / \mathrm{l}(<70 \mathrm{mg} / \mathrm{dl})$ and, if below $3.0 \mathrm{mmol} / \mathrm{l}(54 \mathrm{mg} / \mathrm{dl})$, then exercise should not be restarted

\section{After exercise}

- During the first $90 \mathrm{~min}$ following exercise, a sensor glucose range of $4.4 \mathrm{mmol} / \mathrm{l}$ to $10.0 \mathrm{mmol} / \mathrm{l}(80 \mathrm{mg} / \mathrm{dl}$ to $180 \mathrm{mg} / \mathrm{dl}$ ) might be targeted and $\sim 10-15 \mathrm{~g}$ carbohydrates should be consumed at the lower glucose limit based on the trend arrow

- If an insulin correction is applied due to high sensor glucose levels, then the regular correction factor might be reduced by up to $50 \%$. CGM alarm should set at $4.4 \mathrm{mmol} / \mathrm{l}(80 \mathrm{mg} / \mathrm{dl})$ and those using isCGM system should perform at least one scan during the night-time period

\section{Discussion}

In this position statement, we detailed the use of sensor glucose values accompanied by trend arrows for CGM and isCGM systems for different groups of people with type 1 diabetes and for different sensor glucose responses to exercise. Of note, in this position statement, recommendations for carbohydrate consumption were stratified with respect to the rate of change in glucose for the pre-exercise phase, during exercise, postexercise and the nocturnal post-exercise phase. Taking the lag time of CGM and isCGM systems against SMBG around exercise into account, safe sensor glucose thresholds are recommended for people with type 1 diabetes. In general, these recommendations can be used as an initial guidance tool that also needs to be tailored individually. The recommendations in this position statement will need to be updated in future years to provide the best and most robust evidence-based recommendations for people with type 1 diabetes using CGM and isCGM for glycaemic control during exercise. 
Acknowledgements We want to thank P. Choudhary (King's College Hospital NHS Foundation Trust, London, UK and Department of Diabetes, School of Life Course Sciences, King's College London, London, UK), S. Gray (Campuslife, Swansea University, Swansea, UK), S. Hofer (Department of Pediatrics, Medical University of Innsbruck, Innsbruck, Austria), M. Sauer (Energie Graz GmbH \& Co KG, Graz, Austria) and D. J. West (Population Health Sciences Institute, Newcastle University, Newcastle upon Tyne, UK) for critical assessment of the manuscript before submission. We want to thank F. Aziz, A. Mueller and C. Unteregger (all Cardiovascular Diabetology Research Group, Division of Endocrinology and Diabetology, Medical University of Graz, Graz, Austria) for the support with the production of figures and tables.

Funding This position statement received no specific grant from any funding agency in the public, commercial or not-for-profit sectors.

Authors' relationships and activities $\mathrm{OM}$ has received lecture fees from Medtronic, travel grants from Novo Nordisk A/S, Novo Nordisk AT, Novo Nordisk UK and Medtronic AT, research grants from Sêr Cymru II COFUND fellowship/European Union, Sanofi-Aventis, Novo Nordisk A/S, Novo Nordisk AT, Dexcom Inc., as well as material funding from Abbott Diabetes Care. MCR has received speaker's honorarium from Medtronic and Insulet and has served on advisory boards for Dexcom, Sanofi and Eli Lilly. MLE has received a KESS2/European Social Fund scholarship and travel grants from Novo Nordisk A/S and SanofiAventis. PA has received research support or advisory board fees from Eli Lilly, Novo Nordisk and Roche, funding from Research and Development, Region Halland, and is an employee of Region Halland. RRL reports having received a consumable gift (in kind) from Medtronic. $\mathrm{KN}$ is a shareholder of Novo Nordisk, has received research support from Novo Nordisk, Roche Diagnostics and Zealand Pharma, has received lecture fees from Medtronic, Roche Diagnostics, Rubin Medical, Sanofi, Zealand Pharma, Novo Nordisk and Bayer, and has served on advisory panels for Medtronic, Abbott and Novo Nordisk. NSO has received honoraria for speaking and advisory board participation from Abbott Diabetes, Dexcom, Medtronic Diabetes and Roche Diabetes. DPZ has received speaker's honoraria from Medtronic Diabetes, Ascensia Diabetes and Insulet Corporation. TB has received honoraria for participation on advisory boards for Novo Nordisk, Sanofi, Eli Lilly, Boehringer, Medtronic and Bayer HealthCare, and as a speaker for AstraZeneca, Eli Lilly, Bayer, Novo Nordisk, Medtronic, Sanofi and Roche, and owns stocks of DreaMed Diabetes. CDB has received speaker honoraria from MiniMed Medtronic and is a member of its European Psychology Advisory Board. RMBe has received research support from, consulted for or has been on a scientific advisory board for Abbott Diabetes Care, Dexcom, Eli Lilly, Johnson \& Johnson, Medtronic, Novo Nordisk, Onduo, Roche, Sanofi and United HealthCare. BB received grant support and advisory board fees from Medtronic Diabetes and ConvaTec, grant support and presentation fees from Insulet, advisory board fees from Novo Nordisk and Profusa, grant support from Eli Lilly, grant support and equipment from Dexcom, and is holding patent 61197230 on a hypoglycaemia prediction algorithm. EC is a scientific advisory board member/consultant for Novo Nordisk, Adocia, MannKind, Lexicon and Arecor, and a speaker for Novo Nordisk. TH is a shareholder of Profil, which has received research funds from Adocia, Boehringer Ingelheim, Dance Pharmaceuticals, Eli Lilly, Johnson \& Johnson, MedImmune, Merck Sharp and Dohme, Mylan, Nordic Bioscience, Novo Nordisk, Poxel, Roche Diagnostics, Saniona, Sanofi, Senseonics and Zealand Pharma. SH has served as a consultant or speaker for Lilly, Novo Nordisk, Takeda, Boehringer Ingelheim, Mannkind, Sanofi-Aventis, Zealand Pharma and UN-EEG. LL reports having received speaker honoraria from Animas, Abbott, Insulet, Medtronic, Novo Nordisk, Roche and Sanofi, serving on advisory panels for Animas, Abbott, Novo Nordisk, Dexcom, Medtronic, Sanofi, and Roche, and research support from Novo Nordisk and Dexcom. CM serves or has served on the advisory panel for Novo Nordisk, Sanofi, Merck Sharp and Dohme, Eli Lilly and Company, Novartis, AstraZeneca, Boehringer Ingelheim, Hanmi Pharmaceuticals, Roche, Medtronic, ActoBio Therapeutics, Pfizer, Dianax and UCB. CS reports having received speaker honoraria from Medtronic and Ypsomed, and serving on advisory panels for Novo Nordisk, Medtronic, Roche and Sanofi. MT has received speaker honoraria from MiniMed Medtronic and Novo Nordisk. EGW has received personal fees from Abbott Diabetes Care, Dexcom, Eli Lilly, Medtronic, Novo Nordisk and Sanofi-Aventis. HS has received honoraria, travel support or unrestricted research grants by Amgen, Astra Zeneca, Boehringer Ingelheim, Eli Lilly, MSD, Novo Nordisk and Sanofi-Aventis. PGJ has a financial interest in Pacific Diabetes Technologies Inc., a company that may have a commercial interest in the results of this research and technology. $\mathrm{RMBr}$ has received honoraria as well as travel and educational grant support from Boehringer Ingelheim, Eli Lilly and Company, Novo Nordisk and Sanofi-Aventis. JKM is a member of the advisory board of Boehringer Ingelheim, Eli Lilly, Medtronic, Prediktor A/S, Roche Diabetes Care and Sanofi, and received speaker honoraria from Abbott Diabetes Care, AstraZeneca, Dexcom, Eli Lilly, Medtronic, Merk Sharp \& Dohme, Novo Nordisk A/S, Roche Diabetes Care, Sanofi, Servier and Takeda. The remaining authors have no relevant conflicts of interest to disclose.

Contribution statement All authors of this position statement substantially contributed to conception and design, acquisition of data, or analysis and interpretation of data, drafted the article or revised it critically for important intellectual content and approved the final version to be published.

\section{References}

1. Foster NC, Miller KM, Tamborlane WV, Bergenstal RM, Beck RW (2016) Continuous glucose monitoring in patients with type 1 diabetes using insulin injections. Diabetes Care 39:e81-e82. https://doi.org/10.2337/dc16-0207

2. Beck RW, Riddlesworth T, Ruedy K et al (2017) Continuous glucose monitoring vs conventional therapy for glycemic control in adults with type 1 diabetes treated with multiple daily insulin injections: the gold randomized clinical trial. JAMA 317(4):371. https://doi.org/10.1001/jama.2016.19975

3. van Beers CAJ, DeVries JH, Kleijer SJ et al (2016) Continuous glucose monitoring for patients with type 1 diabetes and impaired awareness of hypoglycaemia (IN CONTROL): a randomised, open-label, crossover trial. Lancet Diabetes Endocrinol 4(11): 893-902. https://doi.org/10.1016/S2213-8587(16)30193-0

4. Lind M, Polonsky W, Hirsch IB et al (2017) Continuous glucose monitoring vs conventional therapy for glycemic control in adults with type 1 diabetes treated with multiple daily insulin injections: the GOLD randomized clinical trial. JAMA 317(4):379-387. https://doi.org/10.1001/jama.2016.19976

5. Bolinder J, Antuna R, Geelhoed-Duijvestijn P, Kröger J, Weitgasser R (2016) Novel glucose-sensing technology and hypoglycaemia in type 1 diabetes: a multicentre, non-masked, randomised controlled trial. Lancet 388(10057):2254-2263. https://doi.org/10.1016/S0140-6736(16)31535-5

6. Oskarsson P, Antuna R, Geelhoed-Duijvestijn P, Kröger J, Weitgasser R, Bolinder J (2018) Impact of flash glucose monitoring on hypoglycaemia in adults with type 1 diabetes managed with multiple daily injection therapy: a pre-specified subgroup analysis of the IMPACT randomised controlled trial. Diabetologia 61(3):539-550. https://doi.org/10.1007/s00125017-4527-5

7. Evans M, Welsh Z, Ells S, Seibold A (2020) The impact of flash glucose monitoring on glycaemic control as measured by $\mathrm{HbAlc}$ : 
a meta-analysis of clinical trials and real-world observational studies. Diabetes Ther 11(1):83-95. https://doi.org/10.1007/s13300019-00720-0

8. Reddy M, Jugnee N, Anantharaja S, Oliver N (2018) Switching from flash glucose monitoring to continuous glucose monitoring on hypoglycemia in adults with type 1 diabetes at high hypoglycemia risk: the extension phase of the I HART CGM study. Diabetes Technol Ther 20(11):751-757. https://doi.org/10.1089/ dia.2018.0252

9. Feig DS, Donovan LE, Corcoy R et al (2017) Continuous glucose monitoring in pregnant women with type 1 diabetes (CONCEPTT): a multicentre international randomised controlled trial. Lancet 390(10110):2347-2359. https://doi.org/10.1016/ S0140-6736(17)32400-5

10. Berg AK, Olsen BS, Thyssen JP et al (2018) High frequencies of dermatological complications in children using insulin pumps or sensors. Pediatr Diabetes 19(4):733-740. https://doi.org/10.1111/ pedi. 12652

11. Hilliard ME, Levy W, Anderson BJ et al (2019) Benefits and barriers of continuous glucose monitoring in young children with type 1 diabetes. Diabetes Technol Ther 21(9):493-498. https:// doi.org/10.1089/dia.2019.0142

12. Messer LH, Berget C, Beatson C, Polsky S, Forlenza GP (2018) Preserving skin integrity with chronic device use in diabetes. Diabetes Technol Ther 20:S254-S264. https://doi.org/10.1089/ dia.2018.0080

13. Messer LH, Johnson R, Driscoll KA, Jones J (2018) Best friend or spy: a qualitative meta-synthesis on the impact of continuous glucose monitoring on life with type 1 diabetes. Diabet Med 35: 409-418. https://doi.org/10.1111/dme.13568

14. Larson NS, Pinsker JE (2013) The role of continuous glucose monitoring in the care of children with type 1 diabetes. Int $\mathrm{J}$ Pediatr Endocrinol 2013(1):8. https://doi.org/10.1186/16879856-2013-8

15. Moser O, Yardley J, Bracken R (2018) Interstitial glucose and physical exercise in type 1 diabetes: integrative physiology, technology, and the gap in-between. Nutrients 10(1):93. https://doi. org/10.3390/nu10010093

16. Larose S, Rabasa-Lhoret R, Roy-Fleming A et al (2019) Changes in accuracy of continuous glucose monitoring using Dexcom G4 Platinum over the course of moderate intensity aerobic exercise in type 1 diabetes. Diabetes Technol Ther 21(6):364-369. https://doi. org/10.1089/dia.2018.0400

17. Steineck IIK, Mahmoudi Z, Ranjan A, Schmidt S, Jørgensen JB, Nørgaard K (2019) Comparison of continuous glucose monitoring accuracy between abdominal and upper arm insertion sites. Diabetes Technol Ther 21(5):295-302. https://doi.org/10.1089/ dia.2019.0014

18. Moser O, Mader J, Tschakert G et al (2016) Point accuracy of interstitial continuous glucose monitoring during resistance and aerobic exercise in type 1 diabetes. Nutrients 8(8):489. https:// doi.org/10.3390/nu8080489

19. Yardley JE, Sigal RJ, Kenny GP, Riddell MC, Perkins BA (2012) Point accuracy of interstitial continuous glucose monitoring during resistance and aerobic exercise in type 1 diabetes. Can J Diabetes 36(5):S14-S15. https://doi.org/10.1016/j.jcjd.2012.07. 063

20. Gilligan BJ, Shults MC, Rhodes RK, Updike SJ (1994) Evaluation of a subcutaneous glucose sensor out to 3 months in a dog model. Diabetes Care 17(8):882-887. https://doi.org/10.2337/diacare.17. 8.882

21. Maahs DM, DeSalvo D, Pyle L et al (2015) Effect of acetaminophen on CGM glucose in an outpatient setting. Diabetes Care 38(10):e158-e159. https://doi.org/10.2337/dc15-1096

22. Zaharieva DP, Turksoy K, McGaugh SM et al (2019) Lag time remains with newer real-time continuous glucose monitoring technology during aerobic exercise in adults living with type 1 diabetes. Diabetes Technol Ther 21(6):313-321. https://doi.org/ 10.1089/dia.2018.0364

23. Mcclatchey PM, Mcclain ES, Williams IM, Gregory JM, Cliffel DWD (2019) Continuous glucose monitor readings lag interstitial glucose by several minutes. Diabetes 68(Supplement 1):962-P (Abstract). https://doi.org/10.2337/db19-962-p

24. Moser O, Eckstein ML, Mueller A et al (2019) Impact of physical exercise on sensor performance of the FreeStyle Libre intermittently viewed continuous glucose monitoring system in people with type 1 diabetes: a randomized crossover trial. Diabet Med 36(5):606-611. https://doi.org/10.1111/dme.13909

25. Moser O, Eckstein ML, McCarthy O et al (2019) Performance of the Freestyle Libre flash glucose monitoring (flash GM) system in individuals with type 1 diabetes: a secondary outcome analysis of a randomized crossover trial. Diabetes Obes Metab 21:25052512. https://doi.org/10.1111/dom.13835

26. Basu A, Dube S, Slama M et al (2013) Time lag of glucose from intravascular to interstitial compartment in humans. Diabetes 62(12):4083-4087. https://doi.org/10.2337/db13-1132

27. Li A, Riddell MC, Potashner D, Brown RE, Aronson R (2019) Time lag and accuracy of continuous glucose monitoring during high intensity interval training in adults with type 1 diabetes. Diabetes Technol Ther 21(5):286-294. https://doi.org/10.1089/ dia.2018.0387

28. Taleb N, Emami A, Suppere C et al (2016) Comparison of two continuous glucose monitoring systems, Dexcom G4 Platinum and Medtronic Paradigm Veo Enlite system, at rest and during exercise. Diabetes Technol Ther 18(9):561-567. https://doi.org/ 10.1089/dia.2015.0394

29. Breton MD, Cherñavvsky DR, Forlenza GP et al (2017) Closedloop control during intense prolonged outdoor exercise in adolescents with type 1 diabetes: the artificial pancreas ski study. Diabetes Care 40(12):1644-1650. https://doi.org/10.2337/dc170883

30. Gomez AM, Gomez C, Aschner P et al (2015) Effects of performing morning versus afternoon exercise on glycemic control and hypoglycemia frequency in type 1 diabetes patients on sensor-augmented insulin pump therapy. J Diabetes Sci Technol 9(3):619-624. https://doi.org/10.1177/ 1932296814566233

31. Jayawardene DC, McAuley SA, Horsburgh JC et al (2017) Closed-loop insulin delivery for adults with type 1 diabetes undertaking high-intensity interval exercise versus moderate-intensity exercise. Diabetes Technol Ther 19(6):340-348. https://doi.org/ 10.1089/dia.2016.0461

32. Zaharieva D, Yavelberg L, Jamnik V, Cinar A, Turksoy K, Riddell MC (2017) The effects of basal insulin suspension at the start of exercise on blood glucose levels during continuous versus circuit-based exercise in individuals with type 1 diabetes on continuous subcutaneous insulin infusion. Diabetes Technol Ther 19(6):370-378. https://doi.org/10.1089/dia.2017.0010

33. Biagi L, Bertachi A, Quirós C et al (2018) Accuracy of continuous glucose monitoring before, during, and after aerobic and anaerobic exercise in patients with type 1 diabetes mellitus. Biosensors 8(1): 22. https://doi.org/10.3390/bios8010022

34. Moser O, Pandis M, Aberer F et al (2019) A head-to-head comparison of personal and professional continuous glucose monitoring systems in people with type 1 diabetes: hypoglycaemia remains the weak spot. Diabetes Obes Metab 21:1043-1048. https://doi. org/10.1111/dom. 13598

35. Aberer F, Hajnsek M, Rumpler M et al (2017) Evaluation of subcutaneous glucose monitoring systems under routine environmental conditions in patients with type 1 diabetes. Diabetes Obes Metab 19(7):1051-1055. https://doi.org/10.1111/dom.12907 
36. Giani E, Macedoni M, Barilli A et al (2018) Performance of the flash glucose monitoring system during exercise in youth with type 1 diabetes. Diabetes Res Clin Pract 146:321-329. https:// doi.org/10.1016/j.diabres.2018.10.001

37. Bally L, Zueger T, Pasi N, Carlos C, Paganini D, Stettler C (2016) Accuracy of continuous glucose monitoring during differing exercise conditions. Diabetes Res Clin Pract 112:1-5. https://doi.org/ 10.1016/j.diabres.2015.11.012

38. Colberg SR, Sigal RJ, Yardley JE et al (2016) Physical activity/ exercise and diabetes: a position statement of the American Diabetes Association. Diabetes Care 39(11):2065-2079. https:// doi.org/10.2337/dc16-1728

39. Riddell MC, Gallen IW, Smart CE et al (2017) Exercise management in type 1 diabetes: a consensus statement. Lancet Diabetes Endocrinol 8587(17):1-14. https://doi.org/10.1016/S22138587(17)30014-1

40. Adolfsson P, Riddell MC, Taplin CE et al (2018) ISPAD clinical practice consensus guidelines 2018: exercise in children and adolescents with diabetes. Pediatr Diabetes 19:205-226. https:// doi.org/10.1111/pedi.12755

41. Battelino T, Danne T, Bergenstal RM et al (2019) Clinical targets for continuous glucose monitoring data interpretation: recommendations from the international consensus on time in range. Diabetes Care 42(8):1593-1603. https://doi.org/10.2337/dci19-0028

42. Chiang JL, Kirkman MS, Laffel LMB, Peters AL (2014) Type 1 diabetes through the life span: a position statement of the American Diabetes Association. Diabetes Care 37(7):2034 2054. https://doi.org/10.2337/dc14-1140

43. American Diabetes Association (2014) Standards of medical care in diabetes-2014. Diabetes Care 37:14-80. https://doi.org/10. 2337/dc14-S014

44. Burckhardt MA, Chetty T, Smith GJ et al (2019) Use of continuous glucose monitoring trends to facilitate exercise in children with type 1 diabetes. Diabetes Technol Ther 21(1):51-55. https://doi.org/10.1089/dia.2018.0292

45. Riddell MC, Milliken J (2011) Preventing exercise-induced hypoglycemia in type 1 diabetes using real-time continuous glucose monitoring and a new carbohydrate intake algorithm: an observational field study. Diabetes Technol Ther 13(8):819-825. https:// doi.org/10.1089/dia.2011.0052

46. Hinkley T, Salmon J, Okely AD, Crawford D, Hesketh K (2012) Preschoolers' physical activity, screen time, and compliance with recommendations. Med Sci Sports Exerc 44(3):458-465. https:// doi.org/10.1249/MSS.0b013e318233763b

47. Bally L, Zueger T, Buehler T et al (2016) Metabolic and hormonal response to intermittent high-intensity and continuous moderate intensity exercise in individuals with type 1 diabetes: a randomised crossover study. Diabetologia 59(4):776-784. https://doi.org/10.1007/s00125-015-3854-7

48. Reddy R, Wittenberg A, Castle JR et al (2019) Effect of aerobic and resistance exercise on glycemic control in adults with type 1 diabetes. Can J Diabetes 43(6):406-414. https://doi.org/10.1016/j. jcjd.2018.08.193

49. Turner D, Gray BJ, Luzio S et al (2016) Similar magnitude of post-exercise hyperglycemia despite manipulating resistance exercise intensity in type 1 diabetes individuals. Scand J Med Sci Sports 26(4):404-412. https://doi.org/10.1111/sms.12472

50. García-García F, Kumareswaran K, Hovorka R, Hernando ME (2015) Quantifying the acute changes in glucose with exercise in type 1 diabetes: a systematic review and meta-analysis. Sports Med 45(4):587-599. https://doi.org/10.1007/s40279-015-0302-2

51. Rabasa-Lhoret R, Bourque J, Ducros F, Chiasson JL (2001) Guidelines for premeal insulin dose reduction for postprandial exercise of different intensities and durations in type 1 diabetic subjects treated intensively with a basal-bolus insulin regimen (ultralente-lispro). Diabetes Care 24(4):625-630. https://doi.org/ 10.2337/diacare.24.4.625

52. West DJ, Morton RD, Bain SC, Stephens JW, Bracken RM (2010) Blood glucose responses to reductions in pre-exercise rapid-acting insulin for $24 \mathrm{~h}$ after running in individuals with type 1 diabetes. J Sports Sci 28(7):781-788. https://doi.org/10.1080/ 02640411003734093

53. Moser O, Eckstein ML, Mueller A et al (2019) Pre-exercise blood glucose levels determine the amount of orally administered carbohydrates during physical exercise in individuals with type 1 diabetes - a randomized cross-over trial. Nutrients 11(6):1287. https://doi.org/10.3390/nu11061287

54. Scott SN, Cocks M, Andrews RC et al (2019) Fasted highintensity interval and moderate-intensity exercise do not lead to detrimental 24-hour blood glucose profiles. J Clin Endocrinol Metab 104(1):111-117. https://doi.org/10.1210/jc.2018-01308

55. Riddell MC, Pooni R, Yavelberg L et al (2019) Reproducibility in the cardiometabolic responses to high-intensity interval exercise in adults with type 1 diabetes. Diabetes Res Clin Pract 148:137-143. https://doi.org/10.1016/j.diabres.2019.01.003

56. Harmer AR, Chisholm DJ, McKenna MJ et al (2007) Highintensity training improves plasma glucose and acid-base regulation during intermittent maximal exercise in type 1 diabetes. Diabetes Care 30(5):1269-1271. https://doi.org/10.2337/dc061790

57. Farinha JB, Boff W, dos Santos GC et al (2019) Acute glycemic responses along 10 -week high-intensity training protocols in type 1 diabetes patients. Diabetes Res Clin Pract 153:111-113. https:// doi.org/10.1016/j.diabres.2019.06.001

58. Bohn B, Herbst A, Pfeifer M et al (2015) Impact of physical activity on glycemic control and prevalence of cardiovascular risk factors in adults with type 1 diabetes: a cross-sectional multicenter study of 18,028 patients. Diabetes Care 38(8):1536-1543. https:// doi.org/10.2337/dc15-0030

59. Lin YK, Hung M, Sharma A et al (2019) Impaired awareness of hypoglycemia continues to be a risk factor for severe hypoglycemia despite the use of continuous glucose monitoring system in type 1 diabetes. Endocr Pract 25(6):517-525. https://doi.org/10. 4158/EP-2018-0527

60. Galassetti P, Tate D, Neill RA, Richardson A, Leu SY, Davis SN (2006) Effect of differing antecedent hypoglycemia on counterregulatory responses to exercise in type 1 diabetes. Am J Physiol Endocrinol Metab 290(6):E1109-E1117. https://doi.org/ 10.1152/ajpendo.00244.2005

61. American Diabetes Association (2020) Older adults: standards of medical care in diabetes-2020. Diabetes Care 43(Suppl. 1):S152S162. https://doi.org/10.2337/dc20-S012

62. Kudva YC, Ahmann AJ, Bergenstal RM et al (2018) Approach to using trend arrows in the freestyle libre flash glucose monitoring systems in adults. J Endocr Soc 2(12):1320-1337. https://doi.org/ 10.1210/js.2018-00294

63. Kennedy A, Nirantharakumar K, Chimen M et al (2013) Does exercise improve glycaemic control in type 1 diabetes? a systematic review and meta-analysis. PLoS One 8(3):e58861. https://doi. org/10.1371/journal.pone.0058861

64. Shivers JP, Mackowiak L, Anhalt H, Zisser H (2013) "Turn it off!": diabetes device alarm fatigue considerations for the present and the future. J Diabetes Sci Technol 7(3):789-794. https://doi. org/10.1177/193229681300700324

65. Eshghi SRT, Yardley JE (2019) Morning (fasting) vs. afternoon resistance exercise in individuals with type 1 diabetes: a randomized cross-over study. J Clin Endocrinol Metab 104(11):52175224. https://doi.org/10.1210/jc.2018-02384

66. McCarthy O, Moser O, Eckstein ML et al (2019) Resistance isn't futile: the physiological basis of the health effects of resistance 
exercise in individuals with type 1 diabetes. Front Endocrinol 10: 507. https://doi.org/10.3389/fendo.2019.00507

67. Peter Adams O (2013) The impact of brief high-intensity exercise on blood glucose levels. Diabetes, Metab Syndr Obes Targets Ther 6:113-122. https://doi.org/10.2147/DMSO.S29222

68. Aronson R, Brown RE, Li A, Riddell MC (2019) Optimal insulin correction factor in post-high-intensity exercise hyperglycemia in adults with type 1 diabetes: the FIT study. Diabetes Care 42(1): 10-16. https://doi.org/10.2337/dc18-1475

69. Turner D, Luzio S, Gray BJ et al (2016) Algorithm that delivers an individualized rapid-acting insulin dose after morning resistance exercise counters post-exercise hyperglycaemia in people with Type 1 diabetes. Diabet Med 33(4):506-510. https://doi.org/10. $1111 /$ dme. 12870

70. Danne T, Nimri R, Battelino T et al (2017) International consensus on use of continuous glucose monitoring. Diabetes Care 40(12): 1631-1640. https://doi.org/10.2337/dc17-1600

71. Cryer PE (2008) The barrier of hypoglycemia in diabetes. Diabetes 57(12):3169-3176. https://doi.org/10.2337/db08-1084

72. Fuchs CJ, Gonzalez JT, Loon LJC (2019) Fructose co-ingestion to increase carbohydrate availability in athletes. J Physiol 597(14): 3549-3560. https://doi.org/10.1113/JP277116

73. Temesi J, Johnson NA, Raymond J, Burdon CA, O'Connor HT (2011) Carbohydrate ingestion during endurance exercise improves performance in adults. J Nutr 141(5):890-897. https:// doi.org/10.3945/jn.110.137075

74. Moser O, Tschakert G, Mueller A et al (2015) Effects of highintensity interval exercise versus moderate continuous exercise on glucose homeostasis and hormone response in patients with type 1 diabetes mellitus using novel ultra-long-acting insulin. PLoS One 10(8):e0136489. https://doi.org/10.1371/journal.pone.0136489

75. Scott SN, Anderson L, Morton JP, Wagenmakers AJM, Riddell MC (2019) Carbohydrate restriction in type 1 diabetes: a realistic therapy for improved glycaemic control and athletic performance? Nutrients 11(5):1022. https://doi.org/10.3390/nu1 1051022

76. Castle JR, Rodbard D (2019) How well do continuous glucose monitoring systems perform during exercise. Diabetes Technol Ther 21:305-309. https://doi.org/10.1089/dia.2019.0132

77. Campbell MD, Walker M, Bracken RM et al (2015) Insulin therapy and dietary adjustments to normalize glycemia and prevent nocturnal hypoglycemia after evening exercise in type 1 diabetes: a randomized controlled trial. BMJ Open Diabetes Res Care 3(1): e000085. https://doi.org/10.1136/bmjdrc-2015-000085

78. Carstens S, Sprehn M (1998) Prehospital treatment of severe hypoglycaemia: a comparison of intramuscular glucagon and intravenous glucose. Prehosp Disaster Med 13(2-4):44-50. https://doi.org/10.1017/s1049023x00030132

79. Maran A, Pavan P, Bonsembiante B et al (2010) Continuous glucose monitoring reveals delayed nocturnal hypoglycemia after intermittent high-intensity exercise in nontrained patients with type 1 diabetes. Diabetes Technol Ther 12(10):763-768. https:// doi.org/10.1089/dia.2010.0038

80. Moser O, Eckstein ML, McCarthy O et al (2019) 66-LB: Greater time spent in hypoglycemia during night compared with day during intensified training in professional cyclists with type 1 diabetes - a prospective observational study. Diabetes 68(Supplement 1):66-LB (Abstract). https://doi.org/10.2337/ db19-66-lb

81. Tsalikian E, Mauras N, Beck RW et al (2005) Impact of exercise on overnight glycemic control in children with type 1 diabetes mellitus. J Pediatr 147(4):528-534. https://doi.org/10.1016/j. jpeds.2005.04.065

82. MacDonald MJ (1987) Postexercise late-onset hypoglycemia in insulin-dependent diabetic patients. Diabetes Care 10(5):584-588. https://doi.org/10.2337/diacare.10.5.584
83. Iscoe KE, Corcoran M, Riddell MC (2008) High rates of nocturnal hypoglycemia in a unique sports camp for athletes with type 1 diabetes: lessons learned from continuous glucose monitoring systems. Can J Diabetes 32(3):182-189. https://doi.org/10.1016/ S1499-2671(08)23008-X

84. Salem MA, Aboelasrar MA, Elbarbary NS, Elhilaly RA, Refaat YM (2010) Is exercise a therapeutic tool for improvement of cardiovascular risk factors in adolescents with type 1 diabetes mellitus? A randomised controlled trial. Diabetol Metab Syndr 2(1):47. https://doi.org/10.1186/1758-5996-2-47

85. Absil H, Baudet L, Robert A, Lysy PA (2019) Benefits of physical activity in children and adolescents with type 1 diabetes: a systematic review. Diabetes Res Clin Pract 156:107810. https://doi.org/ 10.1016/j.diabres.2019.107810

86. D'hooge R, Hellinckx T, Van Laethem C et al (2011) Influence of combined aerobic and resistance training on metabolic control, cardiovascular fitness and quality of life in adolescents with type 1 diabetes: a randomized controlled trial. Clin Rehabil 25(4):349 359. https://doi.org/10.1177/0269215510386254

87. Heyman E, Toutain C, Delamarche P et al (2007) Exercise training and cardiovascular risk factors in Type 1 diabetic adolescent girls. Pediatr Exerc Sci 19(4):408-419. https://doi.org/10.1123/pes.19. 4.408

88. Jabbour G, Henderson M, Mathieu ME (2016) Barriers to active lifestyles in children with type 1 diabetes. Can J Diabetes 40(2): 170-172. https://doi.org/10.1016/j.jcjd.2015.12.001

89. Quirk H, Blake H, Dee B, Glazebrook C (2014) "You can't just jump on a bike and go": a qualitative study exploring parents' perceptions of physical activity in children with type 1 diabetes. BMC Pediatr 14(1):1-12. https://doi.org/10.1186/s12887-0140313-4

90. Erie C, Van Name MA, Weyman K et al (2018) Schooling diabetes: use of continuous glucose monitoring and remote monitors in the home and school settings. Pediatr Diabetes 19(1):92-97. https://doi.org/10.1111/pedi.12518

91. Burckhardt MA, Roberts A, Smith GJ, Abraham MB, Davis EA, Jones TW (2018) The use of continuous glucose monitoring with remote monitoring improves psychosocial measures in parents of children with type 1 diabetes: a randomized crossover trial. Diabetes Care 41(12):2641-2643. https://doi.org/10.2337/dc180938

92. McTavish L, Corley B, Weatherall M, Wiltshire E, Krebs JD (2018) Weight-based carbohydrate treatment of hypoglycaemia in people with type 1 diabetes using insulin pump therapy: a randomized crossover clinical trial. Diabet Med 35(3):339-346. https://doi.org/10.1111/dme.13576

93. Riddell MC, Zaharieva DP, Tansey M et al (2019) Individual glucose responses to prolonged moderate intensity aerobic exercise in adolescents with type 1 diabetes: the higher they start, the harder they fall. Pediatr Diabetes 20(1):99-106. https://doi.org/10. 1111/pedi.12799

94. Admon G, Weinstein Y, Falk B et al (2005) Exercise with and without an insulin pump among children and adolescents with type 1 diabetes mellitus. Pediatrics 116(3):e348-e355. https:// doi.org/10.1542/peds.2004-2428

95. Samuelsson U, Ludvigsson J (2002) When should determination of ketonemia be recommended? Diabetes Technol Ther 4(5):645650. https://doi.org/10.1089/152091502320798286

96. Laffel LMB, Wentzell K, Loughlin C, Tovar A, Moltz K, Brink S (2006) Sick day management using blood 3-hydroxybutyrate (3$\mathrm{OHB}$ ) compared with urine ketone monitoring reduces hospital visits in young people with T1DM: a randomized clinical trial. Diabet Med 23(3):278-284. https://doi.org/10.1111/j.1464-5491. 2005.01771.x

97. Hanas R, Adolfsson P (2017) Bolus calculator settings in wellcontrolled prepubertal children using insulin pumps are 
characterized by low insulin to carbohydrate ratios and short duration of insulin action time. J Diabetes Sci Technol 11(2):247-252. https://doi.org/10.1177/1932296816661348

98. Chetty T, Shetty V, Fournier PA, Adolfsson P, Jones TW, Davis EA (2019) Exercise management for young people with type 1 diabetes: a structured approach to the exercise consultation. Front Endocrinol 10:326. https://doi.org/10.3389/fendo.2019.00326

99. Kaiserman K, Buckingham BA, Prakasam G et al (2013) Acceptability and utility of the mysentry remote glucose monitoring system. J Diabetes Sci Technol 7(2):356-361. https://doi.org/ $10.1177 / 193229681300700211$

100. Montfort-Steiger V, Williams CA (2007) Carbohydrate intake considerations for young athletes. J Sports Sci Med 6:343-352

101. Raju B, Arbelaez AM, Breckenridge SM, Cryer PE (2006) Nocturnal hypoglycemia in type 1 diabetes: an assessment of preventive bedtime treatments. J Clin Endocrinol Metab 91(6): 2087-2092. https://doi.org/10.1210/jc.2005-2798

102. Mauras N, Xing D, Beck RW et al (2010) Prolonged nocturnal hypoglycemia is common during 12 months of continuous glucose monitoring in children and adults with type 1 diabetes. Diabetes Care 33(5):1004-1008. https://doi.org/10.2337/dc092081
103. Franchini S, Comegna L, Prezioso G, Blasetti A (2016) Hypoglycemia in children with type 1 diabetes: unawareness is a concrete risk. Curr Med Res Opin 32(9):1487-1491. https://doi. org/10.1080/03007995.2016.1185400

104. Reddy R, El Youssef J, Winters-Stone K et al (2018) The effect of exercise on sleep in adults with type 1 diabetes. Diabetes Obes Metab 20(2):443-447. https://doi.org/10.1111/dom.13065

105. Taplin CE, Cobry E, Messer L, McFann K, Chase HP, FialloScharer R (2010) Preventing post-exercise nocturnal hypoglycemia in children with type 1 diabetes. J Pediatr 157(5):784-788.e1. https://doi.org/10.1016/j.jpeds.2010.06.004

106. Bachmann S, Hess M, Martin-Diener E, Denhaerynck K, Zumsteg U (2016) Nocturnal hypoglycemia and physical activity in children with diabetes: new insights by continuous glucose monitoring and accelerometry. Diabetes Care 39(7):e95-e96. https://doi. org/10.2337/dc16-0411

Publisher's note Springer Nature remains neutral with regard to jurisdictional claims in published maps and institutional affiliations. 


\section{Affiliations}

\section{Othmar Moser ${ }^{1,2}$ (D) $\cdot$ Michael C. Riddell ${ }^{3}$ (D) Max L. Eckstein ${ }^{1}$ (D) $\cdot$ Peter Adolfsson ${ }^{4,5}$ (D) Rémi Rabasa-Lhoret ${ }^{6,7,8,9}$ (D) Louisa van den Boom ${ }^{10}$ (D) - Pieter Gillard ${ }^{11}$ (D) Kirsten Nørgaard ${ }^{12}$ (D) - Nick S. Oliver ${ }^{13}$ (D) Dessi P. Zaharieva ${ }^{14}$ (D)

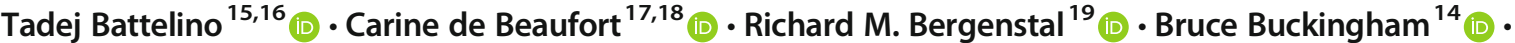 Eda Cengiz ${ }^{20,21}$ (D) - Asma Deeb ${ }^{22}$ (D) - Tim Heise ${ }^{23}$ (D) - Simon Heller ${ }^{24,25}$ (D) - Aaron J. Kowalski ${ }^{26}$ (D) $\cdot$ Lalantha Leelarathna ${ }^{27,28}$ (D) Chantal Mathieu ${ }^{11}$ (D) $\cdot$ Christoph Stettler $^{29}$ (D) Martin Tauschmann $^{30}$ (D) Hood Thabit ${ }^{27}$ (D) - Emma G. Wilmot ${ }^{31,32}$ (1) $\cdot$ Harald Sourij ${ }^{1}$ (I) - Carmel E. Smart ${ }^{33,34}$ (D) Peter G. Jacobs ${ }^{35}$ (D) Richard M. Bracken ${ }^{36}$. Julia K. Mader ${ }^{1}$}

1 Division of Endocrinology and Diabetology, Department of Internal Medicine, Medical University of Graz, Auenbruggerplatz 2, 8036 Graz, Austria

2 Division of Exercise Physiology and Metabolism, Department of Sport Science, University of Bayreuth, Bayreuth, Germany

3 School of Kinesiology and Health Science, York University, Toronto, ON, Canada

4 Department of Pediatrics, The Hospital of Halland, Kungsbacka, Sweden

5 Sahlgrenska Academy at University of Gothenburg, Institution of Clinical Sciences, Gothenburg, Sweden

6 Institut de Recherches Cliniques de Montréal, Montréal, QC, Canada

7 Endocrinology Division Centre Hospitalier Universitaire de Montréal, Montréal, QC, Canada

8 Nutrition Department, Faculty of Medicine, Université de Montréal, Montréal, QC, Canada

9 Montreal Diabetes Research Centre, Montréal, QC, Canada

10 Division of Pediatric Diabetology, DRK Children's Hospital, Siegen, Germany

11 Department of Endocrinology, University Hospitals Leuven, KU Leuven, Leuven, Belgium

12 Steno Diabetes Center Copenhagen, University of Copenhagen, Copenhagen, Denmark

13 Department of Metabolism, Digestion and Reproduction, Faculty of Medicine, Imperial College, London, London, UK

14 Department of Pediatric Endocrinology and Diabetes, Stanford University School of Medicine, Stanford, CA, USA

15 Department of Paediatric Endocrinology, Diabetes and Metabolic Diseases, UMC - University Children's Hospital, University Medical Centre Ljubljana, Ljubljana, Slovenia

16 Faculty of Medicine, University of Ljubljana, Ljubljana, Slovenia

17 Department of Pediatric Diabetes and Endocrinology, Centre Hospitalier Luxembourg, Luxembourg, Luxembourg

18 Department of Pediatrics, Free University Brussels (VUB), Brussels, Belgium
19 International Diabetes Center, Minneapolis, MN, USA

20 Department of Pediatrics, Yale School of Medicine, New Haven, CT, USA

21 Bahçeșehir Üniversitesi, Istanbul, Turkey

22 Paediatric Endocrinology Division, Shaikh Shakhbout Medical City, Abu Dhabi, United Arab Emirates

23 Profil, Neuss, Germany

24 Department of Oncology \& Metabolism, The Medical School, University of Sheffield, Sheffield, UK

25 Sheffield Teaching Hospitals NHS Foundation Trust, Sheffield, UK

26 JDRF, New York, NY, USA

27 Manchester Diabetes Centre, Manchester University NHS Foundation Trust, Manchester Academic Health Science Centre, Manchester, UK

28 Division of Diabetes, Endocrinology and Gastroenterology, Faculty of Biology, Medicine and Health, University of Manchester, Manchester, UK

29 Department of Diabetes, Endocrinology, Nutritional Medicine and Metabolism, Inselspital, Bern University Hospital and University of Bern, Bern, Switzerland

30 Department of Pediatrics and Adolescent Medicine, Medical University of Vienna, Vienna, Austria

31 Diabetes Department, Royal Derby Hospital, University Hospitals of Derby and Burton NHSFT, Derby, UK

32 Faculty of Medicine \& Health Sciences, University of Nottingham, Nottingham, UK

33 School of Health Sciences, University of Newcastle, Callaghan, NSW, Australia

34 Department of Paediatric Diabetes and Endocrinology, John Hunter Children's Hospital, Newcastle, NSW, Australia

35 Department of Biomedical Engineering, Oregon Health \& Science University, Portland, OR, USA

36 Applied Sport, Technology, Exercise and Medicine Research Centre (A-STEM), College of Engineering, Swansea University, Swansea, UK 